\title{
KẾT QUẢ NGHIÊN CÚU THÀNH CỔ LOA (2007 - 2014): TƯ LIỆU VÀ THẢO LUẬN
}

\author{
Trịnh Hoàng Hiệp ${ }^{a^{*}}$
}

${ }^{a}$ Viện Khảo cổ họ, Hà Nội, Việt Nam

*Tác giả liên hệ: Email: hiepkch@gmail.com

Lịch sử bài báo

Nhận ngày 15 tháng 04 năm 2019

Chỉnh sửa ngày 19 tháng 05 năm 2019 | Chấp nhận đăng ngày 01 tháng 08 năm 2019

\section{Tóm tắt}

Kết quả khai quật tại thành Cổ Loa (huyện Đông Anh, Hà Nộ) năm 2007 - 2014 cung cấp nhiều tu liệu mói liên quan đến các giai đoạn xây dụng, kỹ thuật và các kiến trúc phu trợ khác. Theo kết quả nghiên cứu, thành cổ Cổ Loa do vua An Dưong Vuơng xây dựng đã kế thù̀a ngôi thành truớc đó - thành/thành lũy của một ngôi làng phòng thủ tuoơng tụ nhu một hệ thống xã hội nhu tù trương ở giai đoạn muộn của văn hóa Đông Sơn. Tòa thành do An Duơng Vuơng xây dụng lớn hơn nhiều lần so với tòa thành có tù trước, do đó khối luợng công việc phải làm tuoong đưong với một hệ thống xã hội với thực thể chính trị tập trung hoạt động nhu một nhà nuoóc. Nghiên cúu về kỹ thuật xây dựng, quy mô và kiến trúc của tòa thành thể hiện phong cách Việt Nam, rất khác biệt so với phong cách của nhà Hán. Sau thời kỳ vua An Duoong Vuơng, thành Cổ Loa đã được tu sưa nhiều lần ở Thành Trung và Thành Ngoại, mà một trong nhũng lần đó thuộc nhà Lê. Bài viết này giới thiệu tu liệu nghiên cứu thành Cổ Loa trong giai đoạn 2007 - 2014. Thông qua tu liệu sẽ trình bày một số nhận thức, thảo luận về kỹ thuật và các giai đoạn xây/đắp thành lũy; Đặc trung và niên đại; Đặc biệt là lịch sử thành có mối quan hệ nhu thế nào với quá trình dựng nước thời An Duoong Vuong.

Từ khóa: An Dương Vương; Thành Cổ Loa; Văn hóa Đông Sơn.

DOI: http://dx.doi.org/10.37569/DalatUniversity.9.3.560(2019)

Loại bài báo: Bài báo nghiên cứu gốc có bình duyệt

Bản quyền @ 2019 (Các) Tác giả.

Cấp phép: Bài báo này được cấp phép theo CC BY-NC-ND 4.0 


\title{
RESULTS OF RESEARCH INTO CO LOA CITADEL (2007 - 2014): MATERIALS AND DISCUSSION
}

\author{
Trinh Hoang Hiep ${ }^{a^{*}}$
}

${ }^{a}$ The Institute of Archaeological, Hanoi, Vietnam

*Corresponding author: Email: hiepkch@gmail.com

\section{Article history}

Received: April 15 $5^{\text {th }}, 2019$

Received in revised form: May 19 $9^{\text {th }}, 2019 \mid$ Accepted: August $1^{\text {st }}, 2019$

\begin{abstract}
The results from the excavation at Co Loa citadel (Donganh district, Hanoi) in 2007 - 2014 provide many new data on the dates of its building stages, construction techniques, and other architectural features. Co Loa citadel, built by King An Duong, inherited a previous one - the citadel/ramparts of a defensive village from a chiefdom of the late Dong Son period. The citadel built by King An Duong was many times larger than the previous one. Therefore, the workload must have been of a level indicative of a social system with a centralized politic entity functioning as a primitive state. The research into the building techniques, scale, and architecture of the citadel demonstrates the Vietnamese style, which was very different from the Han style. After the period of King An Duong, the middle and outer ramparts of Co Loa citadel were renovated several times, including once under the Le period. This article describes research materials obtained at Co Loa citadel from 2007 to 2014. A discussion about techniques and stages of building the ramparts, the characteristics and chronology of the citadel, and, especially, the relationship between the history of the citadel and the process of state formation in the King An Duong era will be presented.
\end{abstract}

Keywords: Co Loa citadel; Dong Son culture; King An Duong.

DOI: http://dx.doi.org/10.37569/DalatUniversity.9.3.560(2019)

Article type: (peer-reviewed) Full-length research article

Copyright (C) 2019 The author(s).

Licensing: This article is licensed under a CC BY-NC-ND 4.0 


\section{MỞ ĐẦU}

Lịch sử thành Cổ Loa luôn gắn liền với khu di chỉ khảo cổ học Cổ Loa. Chính vì vậy, việc nghiên cứu lịch sử khu di tích Cổ Loa cũng không thể không nghiên cứu thành Cổ Loa và ngược lại. Phạm vi phân bố của khu di tích Cổ Loa bao gồm tất cả những địa điểm có dấu vết thành, lũy hào... trên địa bàn xã Cổ Loa. Phía đông bắc của di tích tới xã Dục Tú, Việt Hùng; Phía tây và tây bắc đến xã Uy Nỗ và phía nam đến xã Đông Hội (Nguyễn \& Vũ̃, 2007) (Hình 1).

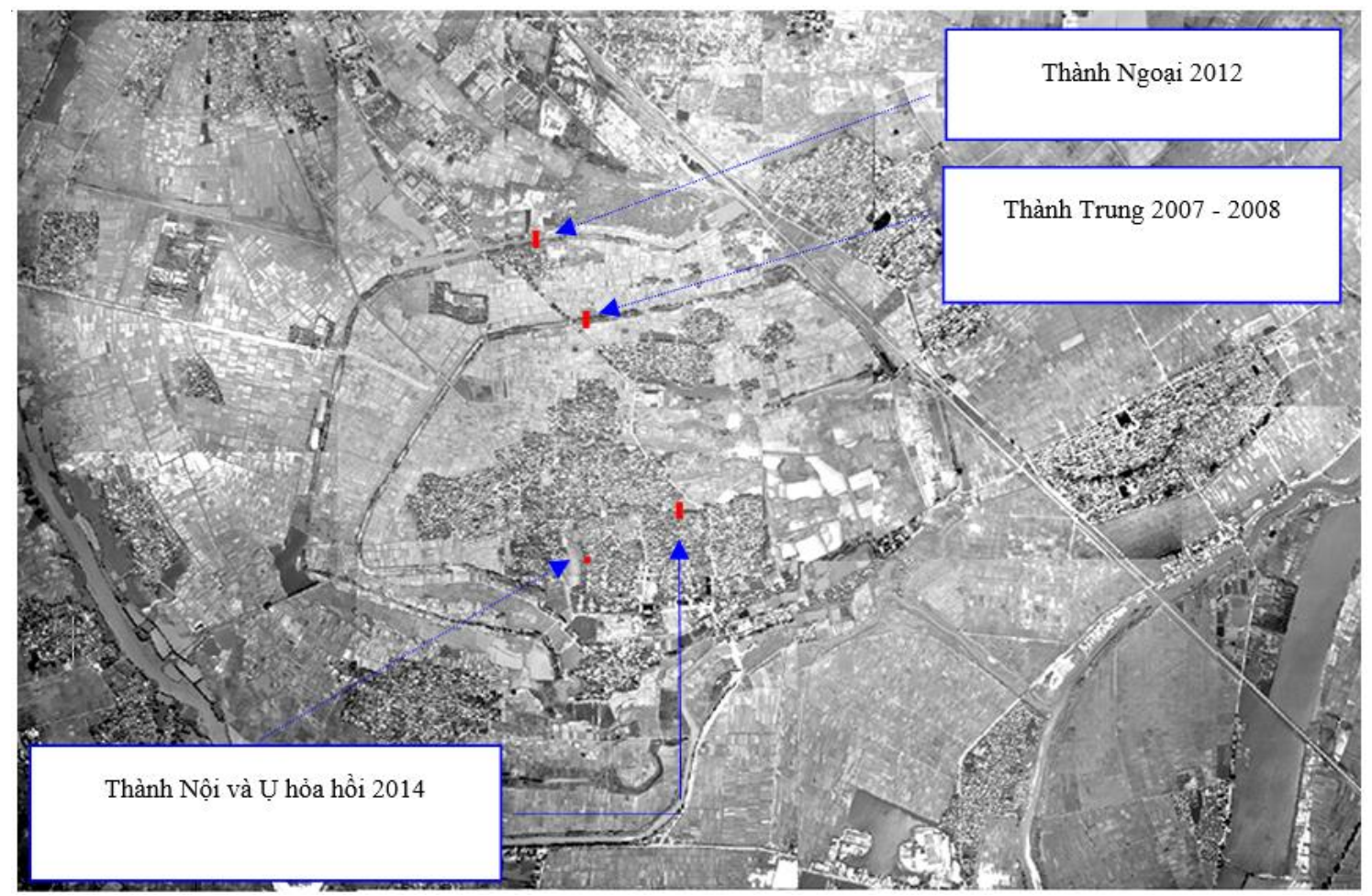

Hình 1. Vị trí các hố khai quật ba vòng thành Cổ Loa (giai đoạn 2007 - 2014)

Nguồn: Trích trong Larew (2003, tr. 14) và Trịnh (2014) cập nhật.

Đến nay, thành Cổ Loa đã được nhắc đến trong nhiều bộ sử cổ của Trung Quốc và Việt $\mathrm{Nam}$. Về cơ bản, các tài liệu trên đều cho rằng thành Cổ Loa ra đời vào thế kỷ III - II trước Công nguyên $(B C$ - Before Christ). Sau cuộc kháng chiến chống Tần thắng lợi vào năm $208 \mathrm{BC}$, An Dương Vương đã thay thế nhà nước của các vua Hùng và chuyển từ Việt Trì về Cổ Loa định đô, cho xây đắp thành kiên cố để phòng vệ và lập ra nhà nước Âu Lạc với thiết chế hoàn chỉnh hơn. Nước Âu Lạc tồn tại trong vòng 30 năm (từ 208BC đến năm Cao Hậu mất năm 179BC), Triệu Đà đã nhân cơ hội phát quân đánh chiếm nước Âu Lạc. Kể từ đây, nước Âu Lạc bị nhà Triệu thống trị. Một số nhà Hán học phương Tây cũng dựa trên các tài liệu đó và thừa nhận có một vương quốc cổ đại ở miền Bắc Việt Nam trước khi có sự xâm lược của người Hán - kinh đô của nhà nước này chính là Cổ Loa.

Tuy nhiên, trong các thư tịch cổ nhiều sự kiện lại không thống nhất về địa điểm, nội dung, cũng như thời gian mở đầu và kết thúc nên rất khó tra cứu, đối sánh để có 
những nhận thức chung thống nhất. Dựa trên các nguồn tư liệu khảo cổ học, đặc biệt là những nghiên cứu về thành Cổ Loa nói riêng, văn hóa Đông Sơn nói chung đã phần nào cho biết về trạng thái kinh tế hay những chuyển biến về trạng thái xã hội - chúng ta dần có một cái nhìn nhận khách quan hơn đối với vấn đề lịch sử này.

Mặc dù nguồn tư liệu ngày càng được bổ sung và hiệu đính nhưng khoảng trống về giai đoạn lịch sử này vẫn còn nhiều vấn đề đã và đang đặt ra. Chính vì vậy, Trung tâm Bảo tồn Di sản Thăng Long - Hà Nội, Viện Khảo cổ học Việt Nam và Khoa Nhân học, Đại học Wisconsin - Madison (Hoa Kỳ) đã hợp tác nghiên cứu ba vòng thành Cổ Loa (giai đoạn 2007 - 2014) (Hình 2). Kết quả khai quật cho thấy, thành Cổ Loa do vua An Dương Vương xây dựng được kế thừa từ tòa thành cổ có từ trước đó nhưng quy mô lớn hơn nhiều. Thành/thành lũy, hào được gia cố và xây dựng nhiều lần, giai đoạn muộn nhất là thời hậu Lê. Có thể nói, di tích và di vật ở Cổ Loa khá phong phú và đa dạng. Nhưng, nghiên cứu này chỉ tập trung giới thiệu kết quả và thảo luận về thành Cổ Loa giai đoạn trước đến hết giai đoạn An Dương Vương. Những di tồn văn hóa thuộc giai đoạn muộn hơn sẽ được giới thiệu trong các nghiên cứu khác. Để tiện theo dõi chúng tôi trình bày kết quả nghiên cứu từ vòng thành Ngoại đến vòng thành Nội như sau.

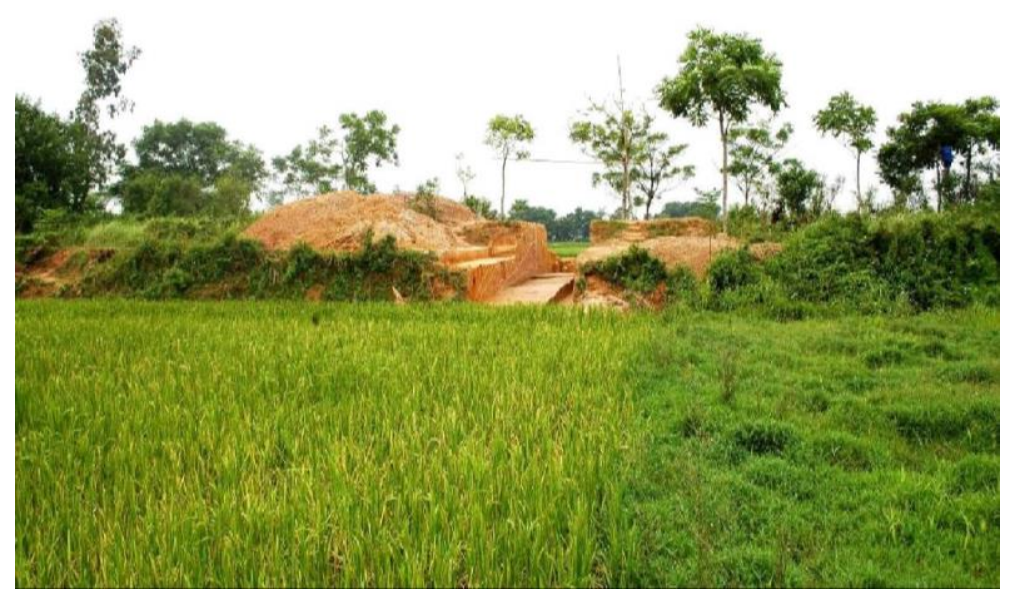

Hình 2. Vị trí hố khai quật địa điểm Thành Ngoại

\section{TƯ LIỆU KHAI QUẬT THÀNH CỔ LOA}

\subsection{Kết quả khai quật Thành Ngoại năm 2012}

Hố khai quật Thành Ngoại có tổng diện tích $72 \mathrm{~m}^{2}(24 \mathrm{~m} \times 3 \mathrm{~m})$, ở dải đất cao của thành, thuộc khu vực gần gò Đống Dân, xóm Bãi, xã Cổ Loa (Đông Anh, Hà Nội).

\subsubsection{Các giai đoạn đắp thành}

Mặt cắt thành lũy trên bề mặt có một bậc ở cả mặt phía bắc và phía nam. Bậc phía nam có thể có chức năng như một lan can phục vụ cho việc bảo vệ sự di chuyển dọc theo gờ phía trong thành và thuận lợi cho việc tấn công khi đối phương tiến đến. Tuy nhiên, ở những vị trí khác nhau của Thành Ngoại còn có những chỗ có ba bậc; Hiện tượng này có thể giải thích là vào giai đoạn muộn với mục đích củng cố thành lũy ở 
những điểm và công năng khác nhau nên đã được gia cố thành ba bậc. Hoặc, cũng có thể vì không đủ nhân lực nên việc tạo thành ba bậc không được thực hiện trên toàn bộ vòng Thành Ngoại.

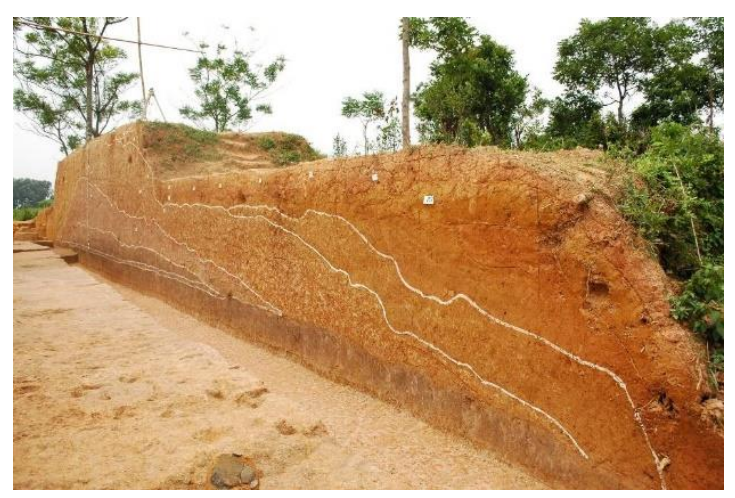

(a)

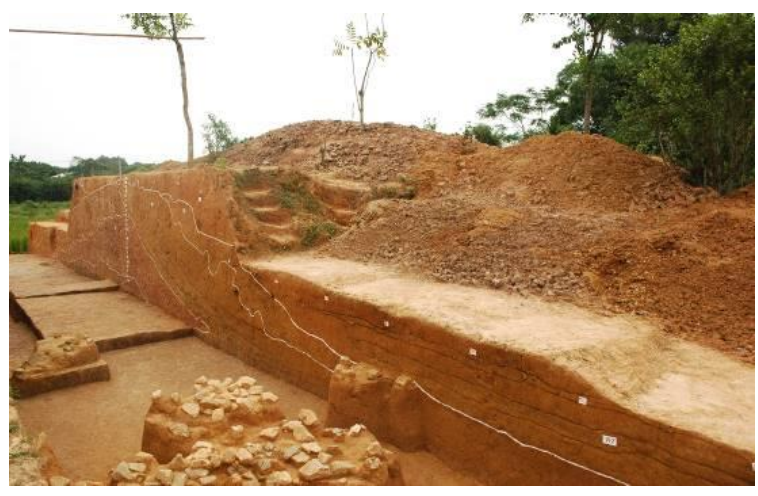

(b)

Hình 3. Các giai đoạn đắp thành

Ghi chú: a) Địa tầng vách tây và b) Địa tầng vách đông.

Căn cứ vào địa tầng và các lớp đất đắp trong quá trình xây dựng có sự khác biệt về kết cấu và màu sắc. Nghiên cứu địa tầng xác định có bốn giai đoạn đắp thành lũy và hai giai đoạn đắp thêm thành. Bốn giai đoạn đắp thành lũy như sau (Hình 3):

- Giai đoạn 1: Đào bỏ lớp đất mặt và đắp lên một lớp đất dày $6 \mathrm{~m}-10 \mathrm{~cm}$, rộng $10.05 \mathrm{~m}$, ở độ sâu so với mặt thành hiện tại là $2.40 \mathrm{~m}-2.69 \mathrm{~m}$. Nền đất dốc từ phía nam về phía bắc (chênh lệch cao độ $29 \mathrm{~cm}$ ), cao ở phía tây dốc về phía đông (chênh lệch $14 \mathrm{~cm}$ ). Bề mặt nền khá bằng phẳng, đôi chỗ hơi lõm xuống, đây có thể là dấu vết của quá trình đầm nền. Nền thành được đắp bằng đất laterite màu đỏ sẫm, nâu, xám đen lẫn hạt sạn sỏi nhỏ và kết cấu cứng. Nền đất này nằm gần như chính giữa thành giai đoạn sớm. Sau khi đắp xong nền thì tiếp tục đắp phủ lên lớp đất laterite màu đỏ sẫm, đất sét màu trắng xám và đất thịt màu xám đen rộng $10.4 \mathrm{~m}$, cao $47-57 \mathrm{~cm}$ (so với mặt nền đất). Với sự tách biệt khá rõ giữa hai lớp đất nên có thể lý giải nền đất này được để một khoảng thời gian khá dài trước khi đắp thêm lớp đất mới (lớp đất laterite). Trong lớp này không phát hiện di vật khảo cổ;

- Giai đoạn 2: Đắp đất laterite có màu đỏ sẫm, nâu, xám đen và lẫn đất sét màu trắng xám về cả hai phía bắc - nam, rộng $14.18 \mathrm{~m}$, cao $1.14 \mathrm{~m}$ (so với mặt nền đất). Đầu phía bắc của Giai đoạn 2 cách đầu nền đất Giai đoạn 1 về phía bắc $1.4 \mathrm{~m}$; Phía nam Giai đoạn 2 cách đầu nền đất $3 \mathrm{~m}$. Chênh lệch cao độ từ phía nam về phía bắc $29 \mathrm{~cm}$. Cũng như lớp 1 , lớp này không phát hiện di vật khảo cổ;

- Giai đoạn 3: Tiếp tục đắp thêm lớp đất laterite màu nâu sẫm lẫn đất sét màu trắng xám; Lớp đất này được ghi nhận từ một phần ở đỉnh của giai đoạn đắp thành lần thứ 2 về phía bắc, rộng $13.46 \mathrm{~m}$, cao $60 \mathrm{~cm}$ so với đỉnh của Giai đoạn 2. Chênh lệch cao độ từ đỉnh đến chân thành (phía bắc) $2.91 \mathrm{~m}$. Ở giai 
đoạn này khi đắp thành còn lẫn những mảnh ngói Cổ Loa ở rìa ngoài chân thành về phía bắc;

- Giai đoạn 4: Đắp lớp đất màu vàng sáng lẫn đất sét màu trắng xám từ một phần Giai đoạn 3 về phía nam, rộng $11.8 \mathrm{~m}$, cao $25 \mathrm{~cm}$ so với đỉnh của Giai đoạn 3 . Chênh lệch cao độ từ đỉnh đến chân về phía nam $232 \mathrm{~cm}$. Gần phần chân thành, về phía nam có lẫn một số mảnh ngói Cổ Loa.

Các giai đoạn đắp thêm thành lũy được thực hiện hai lần như sau:

- Lần thú nhất: Đắp đất laterite màu vàng có lẫn đất sét màu trắng xám về phía bắc và phía nam thành, phủ lên Giai đoạn 3 về phía bắc và Giai đoạn 4 ở phía nam. Trong giai đoạn tu sửa lần thứ nhất này được gia cố nhiều đá và ngói Cổ Loa ở chân thành về phía nam (Hình 4). Đỉnh của lần gia cố thấp hơn mặt thành hiện tại $11 \mathrm{~cm}$, cao $2.39 \mathrm{~m}$ (so với mặt nền đất). Chênh lệch cao độ từ đỉnh đến chân thành phía bắc là $3 \mathrm{~m}$;

- Lần thú hai: Lần tu sửa này được đắp thêm về cả hai phía bắc và nam thành với đất màu nâu đỏ, vàng nhạt pha cát. Diện tích của lần gia cố này như hiện trạng hiện tại, rộng $26 \mathrm{~m}$, cao $2.5 \mathrm{~m}$ (so với mặt nền đất). Chênh lệch cao độ từ đỉnh đến chân là $3.22 \mathrm{~m}$.

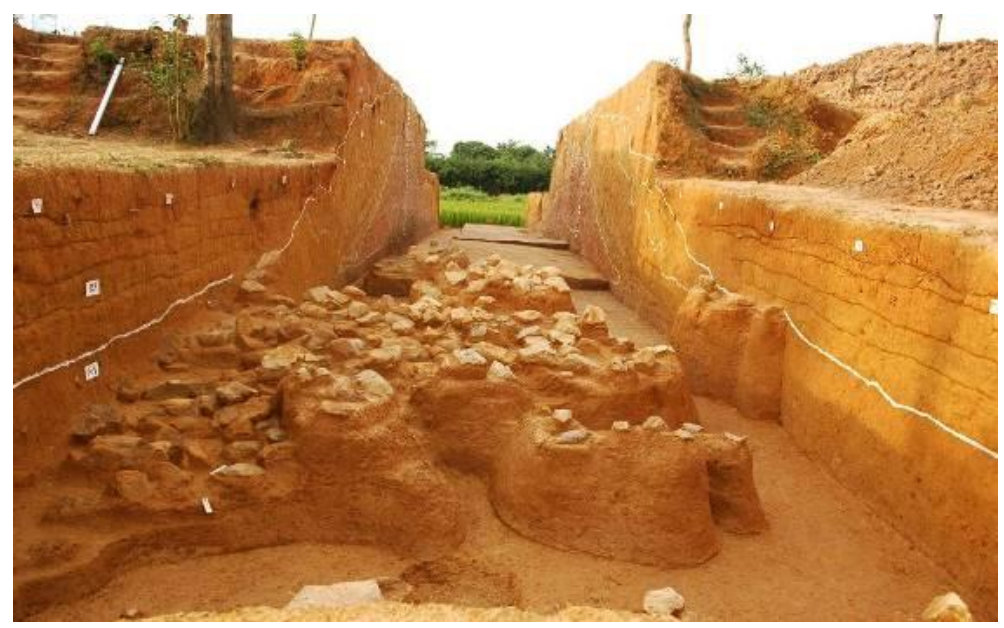

\section{Hình 4. Lớp đá lẫn ngói Cổ Loa ở chân thành phía nam (đắp thêm lần thứ nhất)}

Mặc dù rất khó để xác định thời gian cách nhau giữa các lần đắp thành. Nhưng, chúng tôi cho rằng phần lớn tường thành được cư dân cổ xây dựng liên tục trong một khoảng thời gian tương đối nhanh, có lẽ chỉ một thế hệ thực hiện. Lý giải như trên vì trong địa tầng không có lớp trầm tích tự nhiên hay vết tích của sự xói mòn. Các giai đoạn đắp thành gồm: Giai đoạn 1 đến Giai đoạn 4 là một thời kỳ, sau đó đến giai đoạn đắp thêm thứ nhất nhưng không xa so với thời kỳ trước, thậm chí cũng thuộc giai đoạn này (giai đoạn Cổ Loa). Giai đoạn đắp thêm lần thứ hai thuộc giai đoạn muộn sau này. 


\subsubsection{Divật}

- Ngói Cổ Loa: Có 300 mảnh, gồm hai loại (ngói cong và ngói phẳng). Hoa văn trang trí có các loại: Văn thừng trang trí hai mặt ngói, văn thừng trang trí một mặt ngói, trang trí văn thừng trên lưng và ô trám loại trung bình ở mặt bụng viên ngói, trang trí văn thừng trên lưng và ô trám loại to ở mặt bụng viên ngói... (Hình 5). Những mảnh ngói Cổ Loa chỉ xuất hiện ở giai đoạn đắp thành lũy Giai đoạn 3,4 , và Giai đoạn đắp thêm lần thứ nhất ở chân thành phía bắc, phía nam. Tuy nhiên, ngói và đá tập trung nhiều nhất là ở chân thành về phía nam (Hình 4);

- Mảnh đá: Thường xuất lộ cùng với những mảnh ngói Cổ Loa hoặc ở bình độ thấp hơn gốm một chút (Hình 4). Mảnh đá phiến sét chiếm số lượng áp đảo, ngoài ra còn có đá cuội và đá vôi được cư dân đập nhỏ ra rồi gia cố ở chân thành về phía nam.

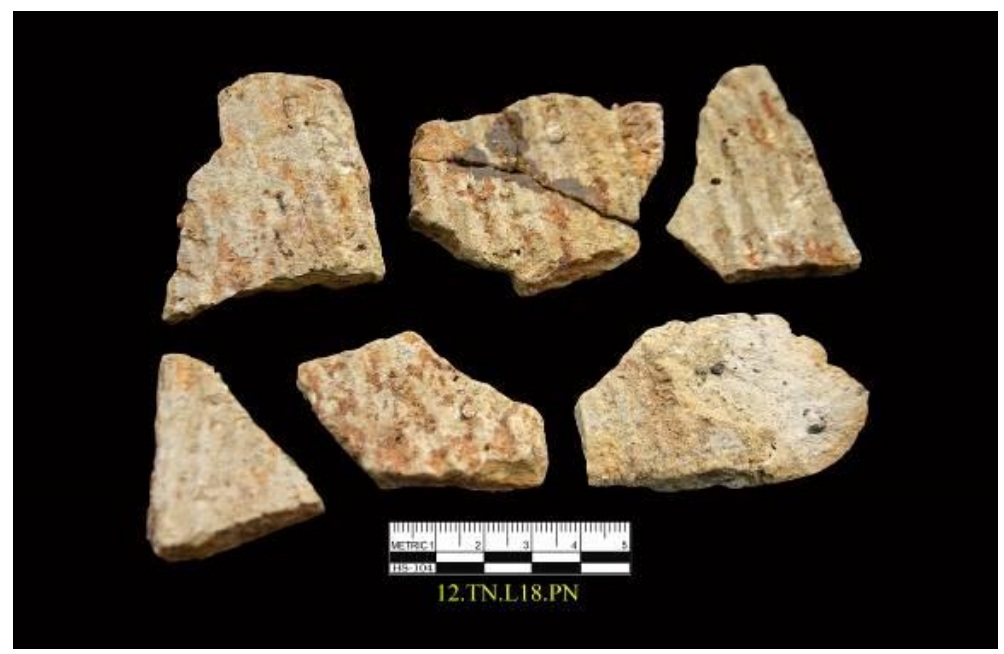

Hình 5. Mảnh ngói Cổ Loa ở phía nam Thành Ngoại

Ngoài ra, ở Thành Ngoại còn phát hiện các mảnh gốm, sành thuộc các giai đoạn nhà Trần, Lê Trung Hưng, Nguyễn (Việt Nam), và ít gốm thời Thanh (Trung Quốc).

\subsection{Kết quả khai quật lũy, hào ở Thành Trung năm 2007 - 2008}

Hai hố khai quật được mở gần cửa Bắc Thành Trung, ở địa phận xóm Thượng và xóm Bãi, xã Cổ Loa. Hố 1 (ký hiệu: H1) cắt ngang Thành Trung diện tích $132.5 \mathrm{~m}^{2}$ (26.5m x 5m), cách cửa Bắc 36m, tọa độ $21^{0} 07^{\prime} 416^{\prime \prime}$ vĩ Bắc, 105052’291” kinh Đông. Hố 2 (ký hiệu: H2) cắt ngang hào Thành Trung diện tích $150 \mathrm{~m}^{2}(30 \mathrm{~m} \times 5 \mathrm{~m})$, cách cửa Bắc 30.4m (Hình 6). 


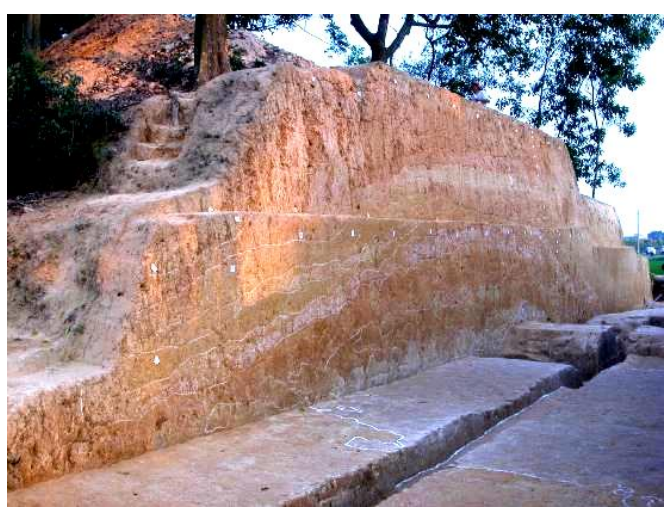

(a)

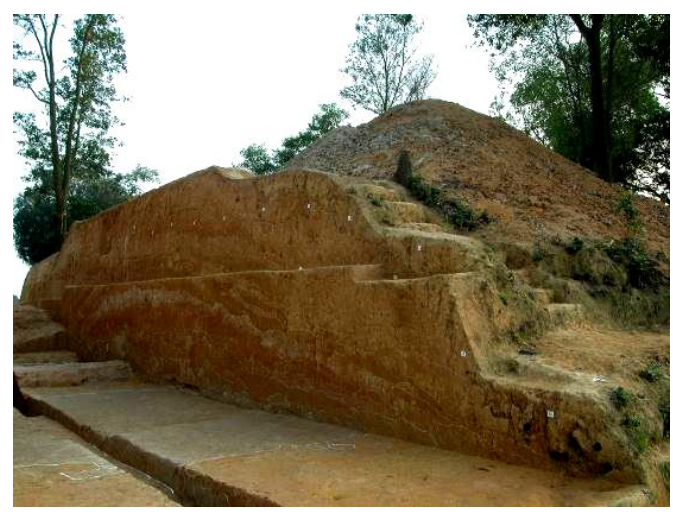

(b)

\section{Hình 6. Địa tầng địa điểm Thành Trung}

Ghi chú: a) Vách đông và b) Vách tây.

\subsubsection{Các lớp đất đắp Thành Trung}

Mặt cắt Thành Trung sâu $4 \mathrm{~m}-4.3 \mathrm{~m}$. Theo màu sắc các lớp đất được chia thành năm lớp. Căn cứ theo kỹ thuật đắp hay số lần đắp được chia thành bốn lớp, thứ tự từ dưới lên trên như sau:

- Lớp 4 (tương đương với Lớp đất 5 ): Là lớp đất đào rãnh từ nền đất gốc (sinh thổ); Hai bên đắp lũy phía trước (phía Bắc) và nền, tường vọng gác (ụ) ở phía sau (phía Nam) (Hình 7). Lũy, tường và nền vọng gác đều đắp bằng đất gốc màu xám đen trước, sau đó có lẽ được đắp phủ thêm lớp đất màu nâu đỏ vào hai bên và bên trên, dày khoảng $5 \mathrm{~cm}-18 \mathrm{~cm}$. Ở chân lũy và nền vọng gác, có thể được gia cố thêm. Khi đắp lớp này có lẽ đất được đầm, và nện kỹ nên không còn dấu vết của viên đất (tự nhiên). Bên trong và cạnh nền vọng gác xuất lộ đồ gốm thuộc văn hóa Đông Sơn (kiểu Làng Cả), đồ sắt và di tích bếp lửa;
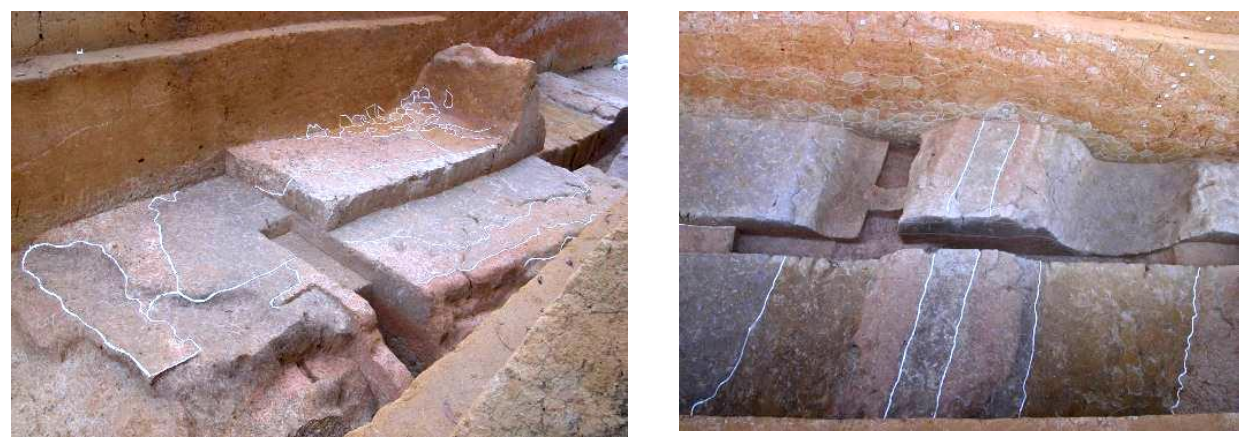

\section{Hình 7. Di tích lũy phòng thủ (vọng gác) giai đoạn văn hóa Đông Sơn nằm bên dưới Thành Trung}

- Lớp 3 (tương đương với Lớp 4 và Lớp 3): Khi đắp Lớp 3, đất được đổ trùm lên trên di tích lũy, nền và tường vọng gác ở dưới đã có từ trước. Đất đổ một cách tự nhiên nên đã tạo thành dạng đống cao hình chóp nón. Trên mặt cắt 
hố khai quật, Lớp 3 gồm các lớp đất màu nâu, trắng xám có dạng cong khum, nhiều viên đất còn nguyên hình dáng ban đầu như hình chữ nhật, hình vuông, hình thang... Lớp 3 không có di vật khảo cổ học;

- Lớp 2 (tương đương với Lớp đất 2): Trước khi đắp Lớp 2, thành được mở rộng bề mặt bằng cách đắp phụ ở hai bên lớp đất pha cát thô màu vàng lẫn nhiều sạn sỏi nhỏ. Mặt thành phía Nam được đắp nhiều và rộng hơn ở phía Bắc. Đất đắp có màu nâu sẫm, nâu vàng phủ trùm lên toàn bộ Lớp 3 và phần đắp mở rộng ở hai bên. Mỗi lần đắp, đất được san phẳng, đầm, và nện kỹ nên Lớp 2 khá phẳng, nằm ngang, đất chặt, mịn, không còn hình thù ban đầu của viên đất như ở Lớp 3. Đất trên cùng của Lớp 2 có màu nâu vàng ở hai bên thành, đặc biệt ở phía nam, xuất lộ lớp ngói Cổ Loa khá dày (Hình 8). Mặt thành phía Nam, ở dưới lớp ngói xuất lộ nhiều đá cuội, sỏi, mảnh đá tự nhiên;

- Lớp 1 (tương đương với Lớp đất 1 ): Đây là lớp trên cùng, đất màu nâu ngả vàng và nâu xám. Dấu vết để lại trên vách hố cho thấy kỹ thuật đắp ở lớp này giống Lớp 2. Hiện vật có một số mảnh ngói Cổ Loa, đồ sành, đồ gốm tráng men thế kỷ XVIII - XIX và hiện vật giai đoạn hiện đại.

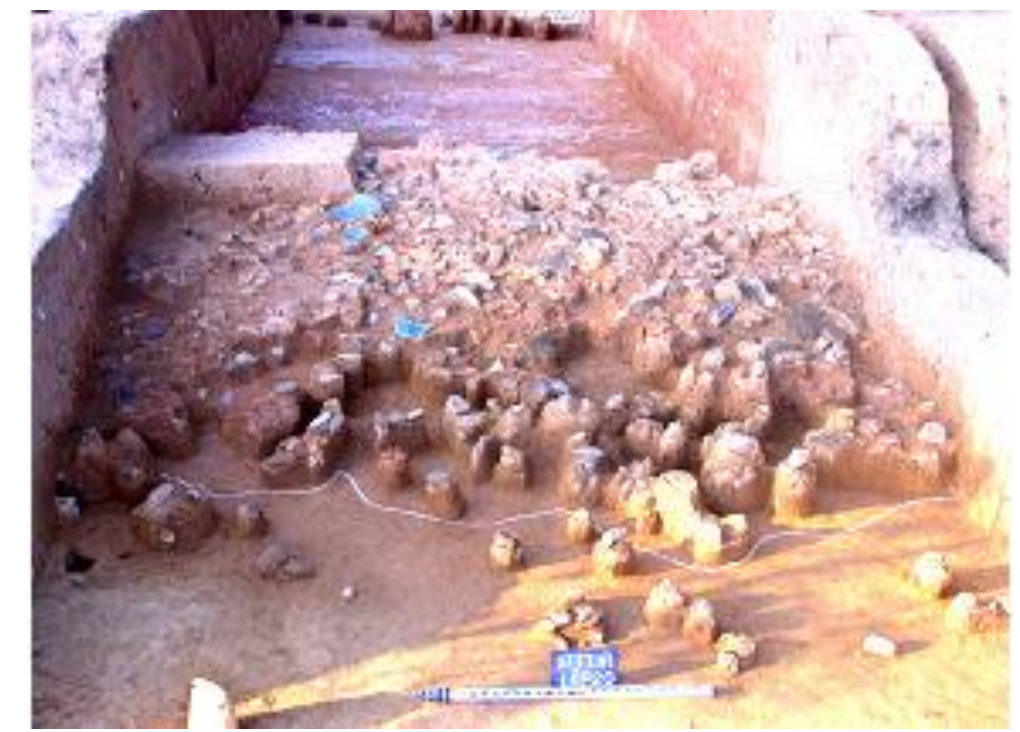

\section{Hình 8. Ngói Cổ Loa và đá ở lớp đắp thành lần 2 (phía nam), địa điểm Thành Trung}

\subsubsection{Các lớp trầm tích hào Thành Trung}

Địa tầng hào Thành Trung sâu 4.8m, từ Lớp 1 đến Lớp 17 có hiện vật khảo cổ. Lớp 18 là lớp đất cát màu nâu loang lổ, không có hiện vật khảo cổ. Căn cứ kết cấu và màu sắc đất, rất có thể đây là sinh thổ và là đáy hào thời kỳ An Dương Vương.

Theo các nhà địa chất, lớp đất sâu nhất có thể là đáy hào tự nhiên nằm sâu thêm $2 \mathrm{~m}$ và có chứa chất hữu cơ thối, mục màu đen. Trầm tích hào Thành Trung có bốn lớp 
chính (không kể lớp mặt hào đang canh tác). Từ dưới lên trên, các lớp trầm tích lắng đọng từ sớm đến muộn như sau (Hình 9):

- Lớp 4: Từ Lớp 17, 16, 15 đất pha nhiều cát màu nâu vàng, lốm đốm loang lổ laterite màu nâu tươi, chứa nhiều đá cuội và ngói Cổ Loa;

- Lớp 3: Từ Lớp 14, 13, 12 đất màu nâu hơi ngả vàng, có hiện vật như Lớp 4;

- Lớp 2: Từ Lớp 10 đến Lớp 4 đất màu xám đỏ, có đồ sành, đồ gốm tráng men, gạch, ngói thế kỷ XV - XIX. Trong lớp này, ở bờ bắc có ba bếp, lò thuộc giai đoạn thời Lê;

- Lớp 1: Gồm Lớp 3 và Lớp 2, đất màu xám đỏ, có di vật giai đoạn hiện đại.

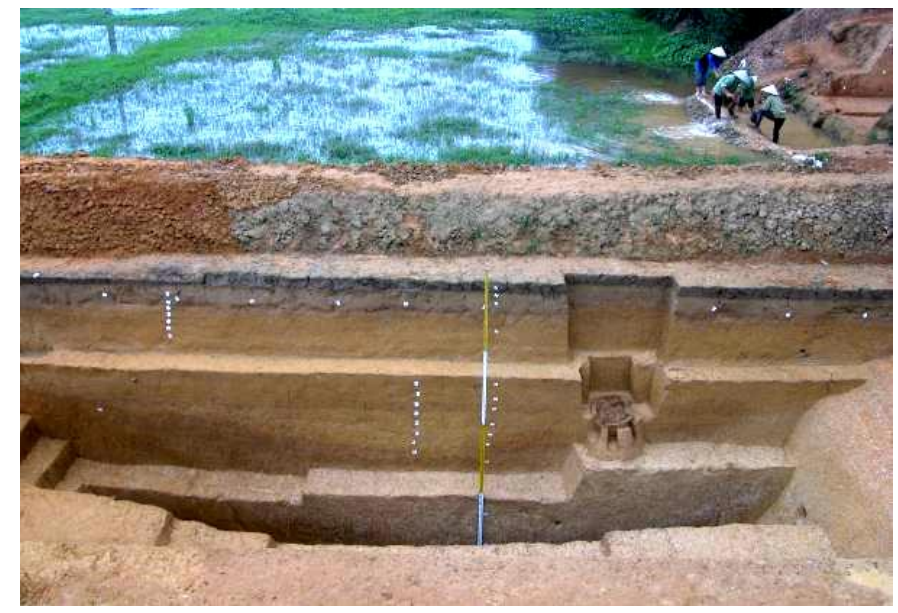

\section{Hình 9. Địa tầng hào Thành Trung}

\subsubsection{Di tích}

- Di tích lũy phòng thủ (vọng gác): Di tích xuất lộ trong lớp đắp Thành 4 (gồm Lớp đất 4 và 3 ); Lớp 4 đắp phủ trùm lên toàn bộ di tích này (Hình 10a). Từ ngoài vào theo bắc - nam, có: Hào - lũy - hào - vọng gác (vọng gác có tường đất cao bảo vệ). Lũy, tường bảo vệ, nền vọng gác được đắp bằng đất đào hào và là đất gốc có màu nâu xám. Sau đó, lũy, tường và nền được đắp dày và cao thêm bên ngoài bằng một lớp đất màu nâu đỏ. Ngoài ra mặt cắt chân lũy còn được gia cố thêm một lớp đất màu nâu sẫm. Vì vậy, lũy có dạng hình thang, chân rộng, đỉnh hẹp (Hình $10 \mathrm{~b}$ và Hình $10 \mathrm{c}$ ). Quy mô toàn bộ di tích xuất lộ trong hố khai quật dài $9.16 \mathrm{~m}$ và rộng $4.87 \mathrm{~m}$. Trong đó lũy đất phía trước cao $1.27 \mathrm{~m}$, đỉnh rộng $45 \mathrm{~cm}$, giữa thân dày $54 \mathrm{~cm}$, và chân rộng $2 \mathrm{~m}$. Nền vọng gác dài $4.4 \mathrm{~m}$, rộng $3.1 \mathrm{~m}$, và cao $31-49 \mathrm{~cm}$. Tường bảo vệ vọng gác cao $4.47 \mathrm{~m}$, rộng đỉnh $45 \mathrm{~cm}$, dày giữa thân $65 \mathrm{~cm}$, chân rộng $1.1 \mathrm{~m}$. Trong nền của vọng gác xuất lộ cụm gốm và đồ sắt thuộc văn hóa Đông Sơn; 
- Di tích bếp: Di tích xuất lộ trong nền lũy phòng thủ có hình gần bầu dục, cửa bếp thấp hướng tây nam, đường dẫn khói chạy dài và cao dần về phía đông bắc. Bếp được đào trực tiếp vào nền vọng gác (Hình 10a và Hình 11a), dấu vết đun nấu để lại trên thành bếp một lớp đất cháy màu nâu đỏ tươi có xu hướng đậm ở trong và nhạt dần ra ngoài. Đây là tác động của nhiệt độ qua quá trình đun/nấu. Bếp có kích thước không lớn, tính cả tường hai bên, bếp rộng $33.5 \mathrm{~cm}$, đường thoát khói dài $43 \mathrm{~cm}$, rộng trung bình $15 \mathrm{~cm}$. Trong bếp có than tro và một vài mảnh gốm văn hóa Đông Sơn (Hình 11);

- Cụm gốm văn hóa Đông Sơn trong và cạnh nền vọng gác: Những mảnh gốm tập trung khá dày đặc, gốm màu nâu xám, rất mềm. Di tích này được giữ lại để bảo tồn tại chỗ (Hình 12). Cạnh cụm gốm còn phát hiện di vật sắt, có thể là một con dao đã bị gỉ. Hiện tượng xuất hiện gốm Đông Sơn dưới chân Thành Trung giống như trường hợp ở di chỉ Đường Mây dưới Thành Ngoại tại Xóm Vang;

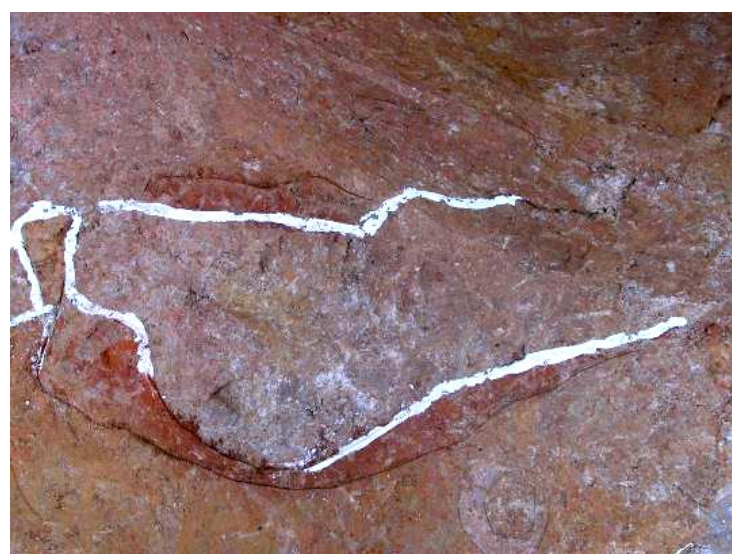

(a)

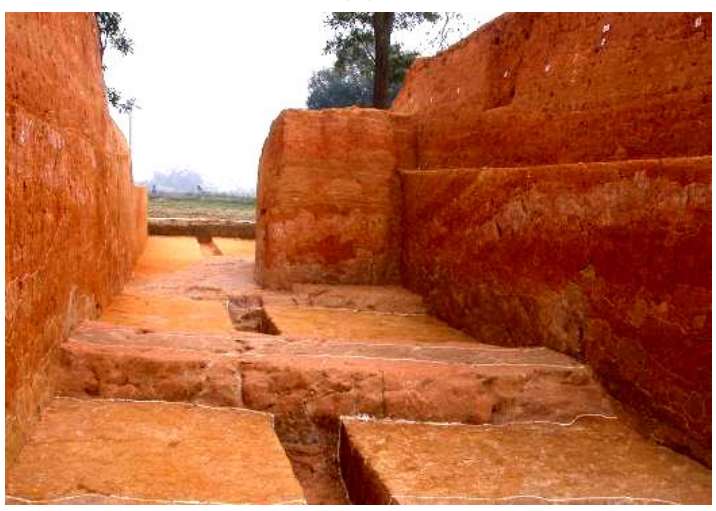

(c)

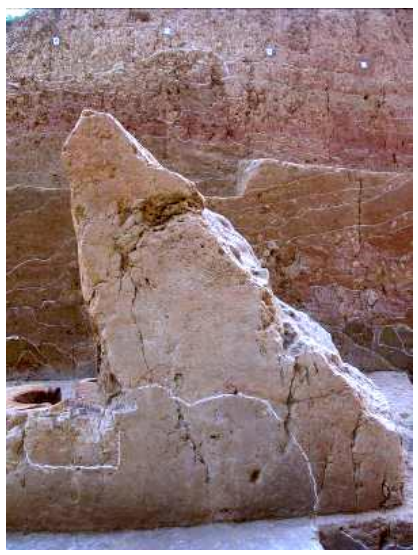

(b)

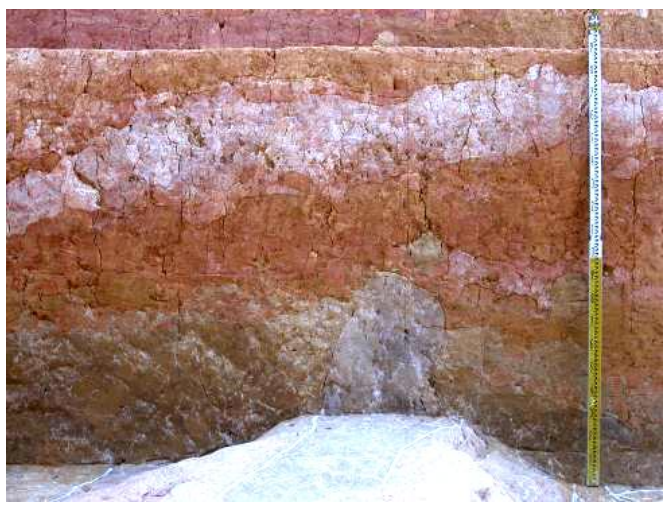

(d)

Hình 10. Di tích lũy phòng thủ (vọng gác)

Ghi chú: a) Đất qua lửa (bếp)?; b) Mặt cắt lũy phòng thủ; c) Di tích lũy phòng thủ; và d) Lớp thành 3 đắp trùm lên Lớp 4. 


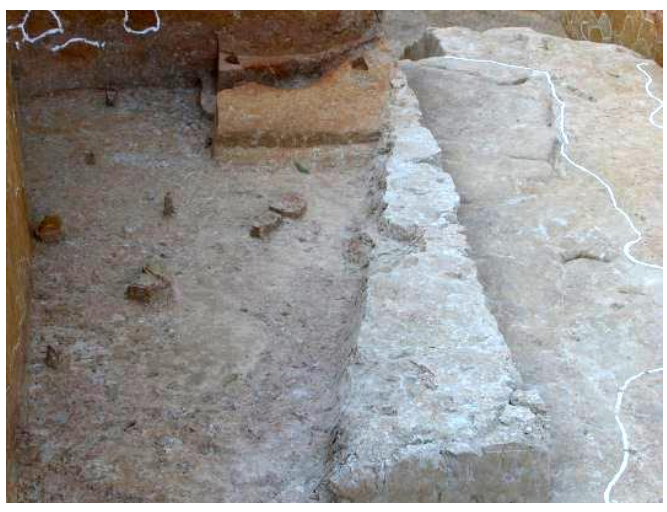

(a)

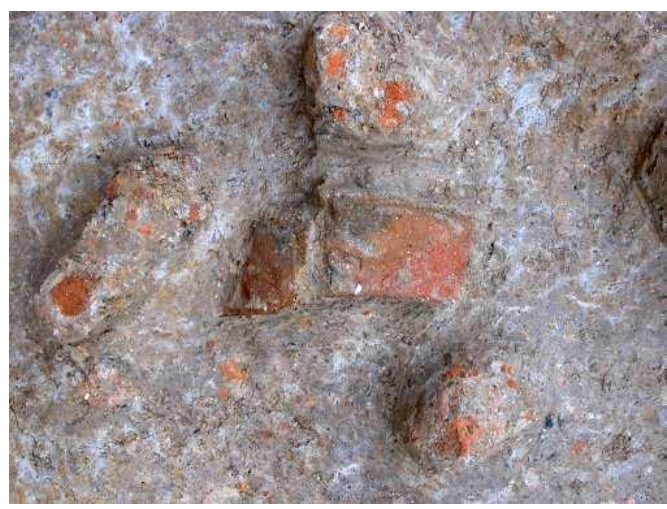

(b)

\section{Hình 11. Di tích bếp}

Ghi chú: a) Di tích bếp lửa trong nền vọng gác và b) Mảnh gốm Đông Sơn trong trong vọng gác.
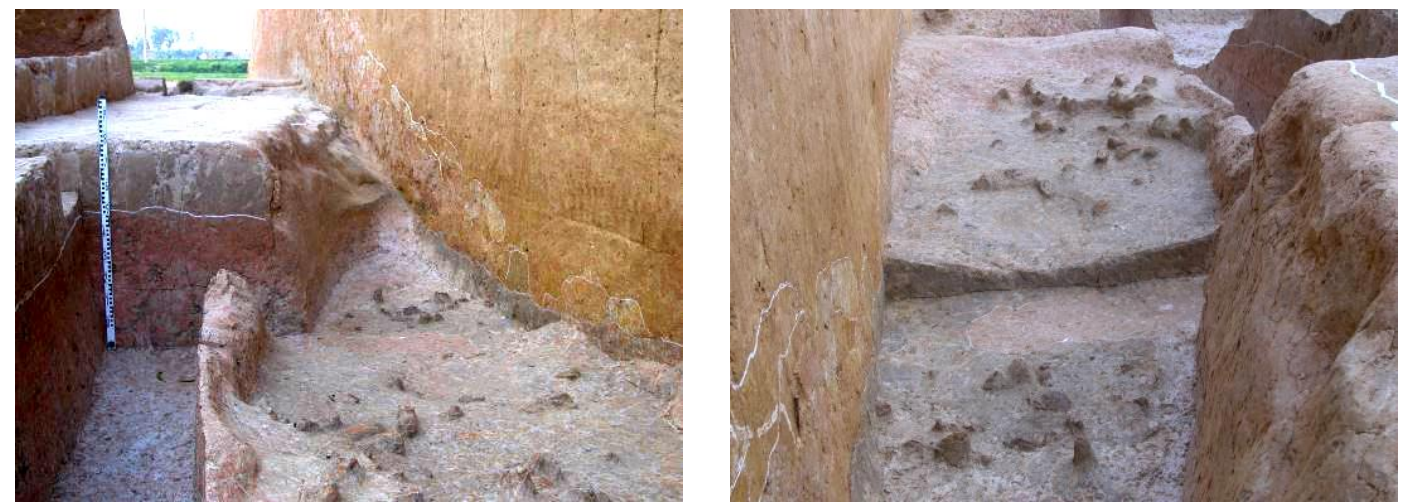

Hình 12. Cụm gốm văn hóa Đông Sơn cạnh nền vọng gác

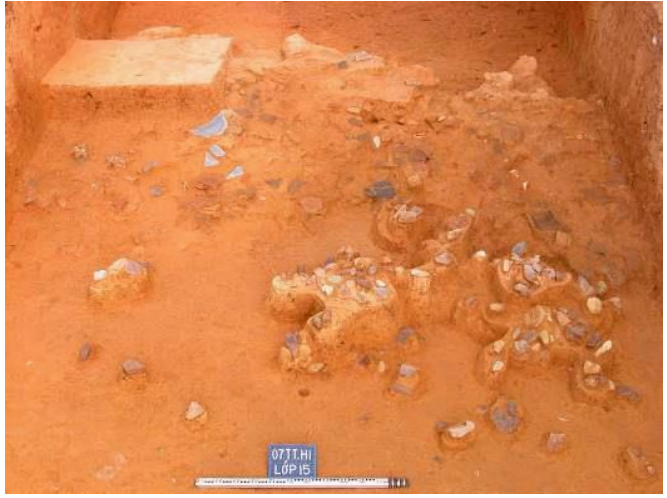

(a)

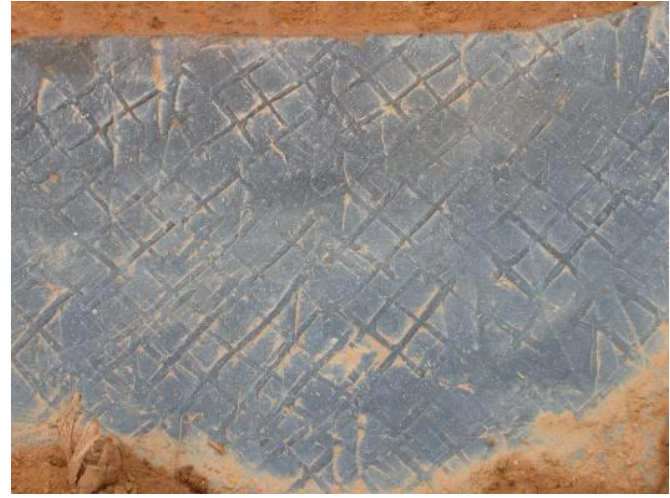

(b)

Hình 13. Di tích tập trung ngói Cổ Loa và đá (F1)

Ghi chú: a) Đá xuất lộ cùng ngói Cổ Loa ở mặt thành phía nam; b) Chi tiết hoa văn trên mặt trong ngói

- Di tích tập trung ngói Cổ Loa và đá: Di tích được ký hiệu F1 là dải ngói Cổ Loa ở mặt phía nam thành (Hình 13) và di tích $\mathrm{F} 2$ là dải ngói Cổ Loa ở mặt phía bắc thành. Cả hai dải ngói này đều nằm cách mặt thành hiện nay 70 - 
$90 \mathrm{~cm}$. Mật độ gốm ở mặt phía nam thành thường dày đặc, phân bố rộng, dày $20-30 \mathrm{~cm}$, lẫn với những viên đá cuội. Ở $\mathrm{F} 2$, dải gốm xuất lộ rải rác và mỏng hơn hơn F1 (dày $15-20 \mathrm{~cm}$ ).

\subsubsection{Di vạt}

- Đồ gốm văn hóa Đông Sơn: Khu vực phát hiện nhiều gốm nhất là ở trong và bên cạnh nền ụ phòng vệ $(\mathrm{H} 1)$, số lượng thu được 57 mảnh. Phần lớn gốm văn hóa Đông Sơn trong di tích lũy phòng vệ $(\mathrm{H} 1)$ được giữ lại bảo tồn tại chỗ. Gốm ở đây vỡ vụn, không có hiện vật nguyên. Gốm màu nâu xám hoặc xám đen thường được trang trí văn thừng; Gốm có màu xám hay nâu vàng không được trang trí hoa văn. Về loại hình, trong 57 mảnh gốm Đông Sơn thu được có hai mảnh miệng, loại miệng loe, không trang trí hoa văn, đường kính miệng $24 \mathrm{~cm}$. Trong 55 mảnh thân có 17 mảnh được trang trí văn thừng (loại mịn và vừa). Các mảnh thân có độ dày trung bình $1 \mathrm{~cm}$, mảnh dày nhất $1.5 \mathrm{~cm}$ (thống nhất đánh ký tự Hố theo trên: $\mathrm{H} 1, \mathrm{H} 2$ ).

- Ngói Cổ Loa: Ngói xuất lộ ở sườn trong (sườn phía nam thành), độ sâu 70 $90 \mathrm{~cm}$ so với mặt thành hiện đại. Mặt phía bắc thành cũng tìm thấy ngói nhưng không nhiều. Ngói ở đây có dạng cong và phẳng. Tuy nhiên, trong hố cắt lũy - hào Thành Trung chỉ phát hiện được loại ngói cong. Về loại hình ngói có hai loại: i) Ngói âm có 5,424 mảnh (hố H1: 5,133 mảnh, hố H2: 291 mảnh). Trong đó có 4,533 mảnh trang trí hoa văn, 891 mảnh không trang trí hoa văn và không xác định; và ii) Ngói duoong có 171 mảnh (hố H2: 166 mảnh, hố H1: 5 mảnh). Trong đó, cổ ngói có chín mảnh (bảy mảnh trang trí văn thừng hai mặt và hai mảnh không rõ hoa văn), thân ngói có 166 mảnh;

- Đồ đá: Đồ đá thường xuất lộ cùng với ngói Cổ Loa hoặc ở bình độ thấp hơn một chút, hiện vật thu được gồm: i) Di vật đá phân bố chủ yếu từ Lớp 9 trở xuống, cách mặt hố $90-100 \mathrm{~cm}$. Trong H1 phát hiện được 1,223 di vật, trong đó 917 di vật là ở các lớp đất đào và 306 di vật trong $F 1$ và $F 2$. Trong số 917 di vật đá có 33 công cụ, gồm: 13 hòn ghè, 5 chày, 3 hòn ghè, 11 bàn mài, và 1 phác vật khuôn đúc mũi tên đồng. Về chất liệu, đá phiến sét chiếm số lượng áp đảo. Đây là loại đá mềm, chịu được nhiệt độ cao nên thường được cư dân đương thời dùng làm khuôn đúc hiện vật kim loại. Trong di tích Đền Thượng ở các cuộc khai quật năm 2004 - 2008, các nhà khảo cổ cũng đã phát hiện hàng trăm hiện vật khuôn đúc mũi tên đồng như ở Cổ Loa; Đáng chú ý là đã tìm thấy hàng nghìn cục đá nguyên liệu, phác/phế vật, và phế liệu trong quá trình làm khuôn đúc mũi tên đồng. Với sự có mặt của số lượng lớn nguyên liệu đá dùng làm khuôn đúc ở Thành Trung và những phác vật khuôn đúc là những cứ liệu quý để khẳng định việc đúc mũi tên đồng của cư dân Âu Lạc thời An Dương Vương tại kinh đô Cổ Loa là có cơ sở; và ii) $H 2$ : Có 354 di vật, gồm ba bàn mài, một hòn ghè, và 350 mảnh đá khác. 
Ngoài ra, ở Thành Trung còn phát hiện đồ gốm men và đồ sành thuộc các giai đoạn sau thời An Dương Vương. Những di vật này thuộc các giai đoạn nhà nước phong kiến của Việt Nam và Trung Quốc (nhà Thanh).

\subsection{Khai quật Ụ hỏa hồi và Thành Nội năm 2014}

\subsubsection{Khai quật Ụ hỏa hồi}

Chúng tôi mở ba hố khai quật với tổng diện tích $67 \mathrm{~m}^{2}$. Trong đó, $\mathrm{H} 1$ có diện tích $48 \mathrm{~m}^{2}(16 \times 3 \mathrm{~m}), \mathrm{H} 2$ diện tích $9 \mathrm{~m}^{2}(3 \times 3 \mathrm{~m})$, và $\mathrm{H} 3$ có diện tích $10 \mathrm{~m}^{2}(4 \times 2.5 \mathrm{~m})$ tại địa điểm Ụ hỏa hồi, có tọa độ $21^{0} 115^{\prime} 80^{\prime \prime}$ vĩ Bắc, $105^{\circ} 87^{\prime} 532$ " kinh Đông, nằm ở phía đông bắc Thành Nội, thuộc thôn Chợ, xã Cổ Loa (Hình 14, Hình 15, và Hình 16).

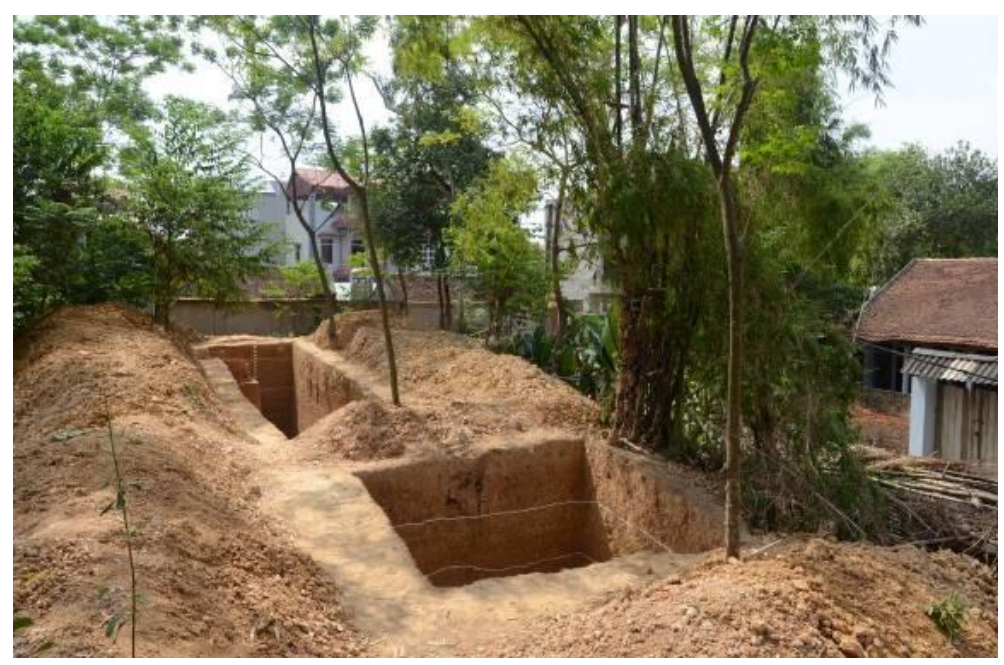

Hình 14. Hố khai quật Ụ hỏa hồi Thành Nội phía đông bắc

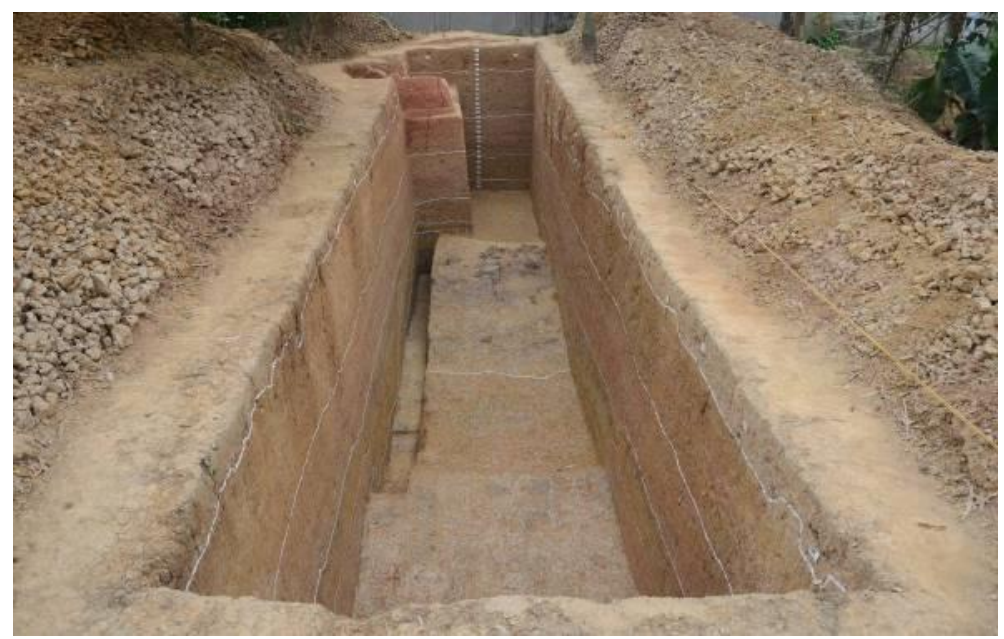

Hình 15. Tổng thể mặt bằng Thành Nội và Ụ hỏa hồi 


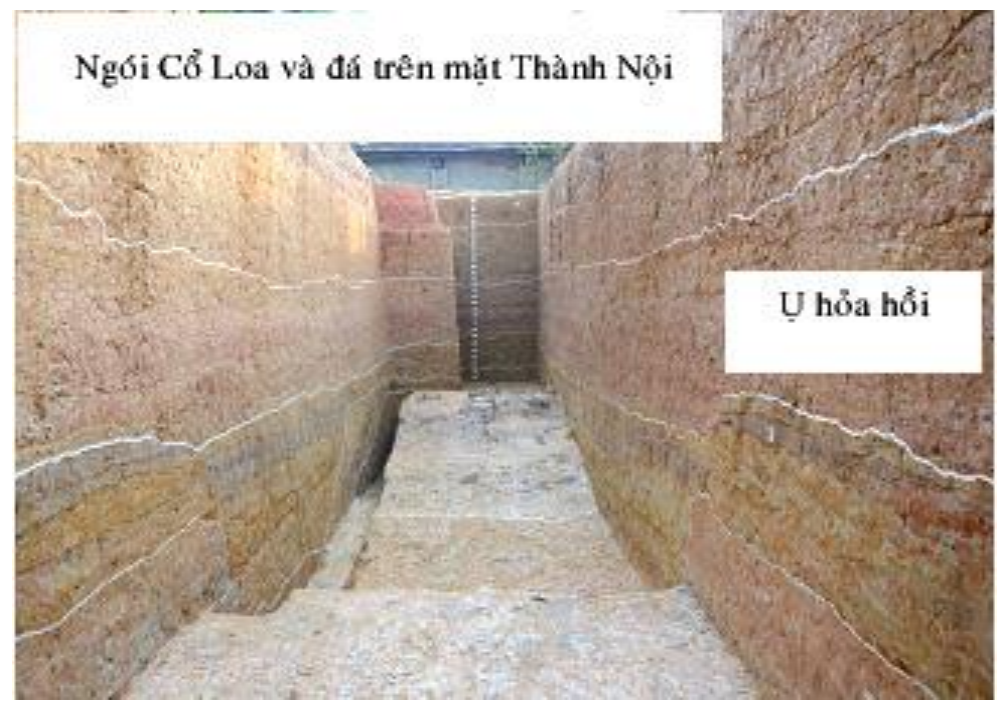

Hình 16. Thành Nội và Ụ hỏa hồi phía đông bắc

Căn cứ vào địa tầng, từ sự khác biệt của các lớp đất đắp có thể nhận thấy có bốn giai đoạn đắp lũy Thành Nội và Ụ hỏa hồi phía đông bắc như sau (Hình 17):

- Lần 1 (Giai đoạn 1): Đào xuống lớp đất tự nhiên $70-100 \mathrm{~cm}$ rồi đắp thành lũy về phía nam với cao độ chênh lệch theo thế dốc từ phía nam về phía bắc $76 \mathrm{~cm}$. Đất đắp thành lũy là đất sét màu nâu hơi vàng (chiếm chủ yếu) và đất sét màu xám. Trên bề mặt thành lũy có rất nhiều mảnh ngói Cổ Loa và đá nằm về phía bắc. Bề mặt thành/lũy dài $3.9 \mathrm{~m}$. Diện tích mặt thành tập trung nhiều mảnh ngói Cổ Loa, đá, than (dài $2.81 \mathrm{~m}$ ), tiếp tục phát triển về hai phía đông và tây hố khai quật, tương đương với phạm vi chân Thành Nội. Mặt và chân Thành Nội ở Giai đoạn 1 có độ sâu so với mặt Ụ hỏa hồi hiện tại 3.50 $4.04 \mathrm{~m}$. Phía bắc Thành Nội là Ụ hỏa hồi cao $55-58 \mathrm{~cm}$, mặt Ụ hỏa hồi khá bằng phẳng, được đắp bằng đất laterite màu đỏ chiếm số lượng lớn, lẫn đất sét màu vàng sẫm và đất sét màu xám. Dựa trên sự tách biệt khá rõ giữa giai đoạn đắp lần 1 và 2 thì có thể lý giải là sau khi đắp xong Thành Nội và Ụ hỏa hồi (Giai đoạn 1) một khoảng thời gian nhất định thì cư dân mới đắp phủ lên nền đất tiếp theo (Giai đoạn 2);

- Lần 2 (Giai đoạn 2): Đắp đất lên toàn bộ các di tích của Giai đoạn 1 , lần đắp này có độ dày trung bình $13-105 \mathrm{~cm}$, là đất sét màu nâu hơi vàng chiếm tỷ lệ lớn, lẫn đất sét hơi xám, xám, nâu, nâu xám tối và đất laterite màu đỏ. Tuy nhiên, phần đất đắp lên Ụ hỏa hồi (Giai đoạn 1) về phía bắc được đắp cao hơn bề mặt đất đắp Thành Nội và Ư hỏa hồi giai đoạn này về phía nam (trung bình $40 \mathrm{~cm}$ ). Việc đắp thêm đất để tạo mặt bằng vào Giai đoạn 2 được đắp đất theo địa hình vốn có từ trước. Trong lần đắp thêm này có những nơi tập trung nhiều mảnh ngói, than tro dày $4-10 \mathrm{~cm}$, rộng $1.2-1.7 \mathrm{~m}$ và phát triển về hai phía đông và tây của hố khai quật. Đất trong khu vực này là đất sét màu xám chiếm tỷ lệ lớn, lẫn đất sét màu trắng xám, màu vàng sẫm và 
màu đỏ sẫm. Di tích nằm ở độ sâu $2.06 \mathrm{~m}$ so với bề mặt Ụ hỏa hồi hiện tại về phía tây. Đắy di tích nằm cao hơn so với bề mặt Ụ hỏa hồi Giai đoạn 1 là $52 \mathrm{~cm}$. Ngoài ra, ở Thành Nội còn phát hiện thêm di tích lò nung ngói giai đoạn thế kỷ XIII - XIX;

- Lần 3 (Giai đoạn 3): Lần đắp này dày 40 - 130cm, tạo cho bề mặt Ử hỏa hồi và Thành Nội khá bằng phẳng. Được đắp từ đất laterite màu đỏ lẫn sạn sỏi màu đen chiếm tỷ lệ lớn lẫn đất sét màu nâu hơi xám, màu nâu vàng và màu nâu. Trong giai đoạn đắp thêm này có di tích ký hiệu F1 tập trung nhiều mảnh ngói Cổ Loa, than tro. Di tích nằm trong lớp đất sét màu xám hơi sáng loang lổ lẫn đất laterite màu đỏ sẫm và đất sét màu xám sẫm. Di tích tiếp tục phát triển sang phía đông và phía tây hố khai quật;

- Lần 4 (Giai đoạn 3): Dày $58-140 \mathrm{~cm}$, được đắp từ đất sét màu nâu hơi vàng sáng có tỷ lệ lớn lẫn đất laterite màu đỏ, đất sét màu nâu vàng nhạt;

- Lần 5 (Giai đoạn 4): Dày 20 - 120cm, đất sét màu xám, màu nâu sẫm.

\section{Lân 5 (giai đọan 4)}

Lân 4 (giai đọan 3)

Lấn 3 (giai đoạn 2)

Lân 2 (giai đọan 2)

Lân 1 (giai đọạn 1)

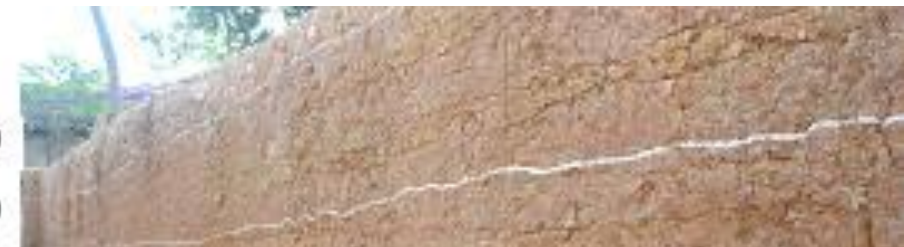

\section{Hình 17. Các lớp đất đắp Thành Nội và Ụ hỏa hồi}

Hiện tại rất khó xác định khoảng thời gian giữa các lần đắp Thành Nội và Ụ hỏa hồi nhưng nhận định ban đầu của chúng tôi là lũy Thành Nội và Ụ hỏa hồi được xây dựng liên tục, trong một khoảng thời gian ngắn, có lẽ duy nhất một thế hệ thực hiện. Lý giải cho nhận định trên là vì địa tầng không có lớp trầm tích tự nhiên/xói mòn, đó có thể là những khoảng trống lớn về thời gian giữa các giai đoạn đắp thành và U hỏa hồi. Ngoại trừ Lần 1 (Giai đoạn 1 ), theo chúng tôi có thể được đắp xong toàn bộ vòng Thành Nội cũng như Ụ hỏa hồi thì cư dân lúc đó mới quay lại đắp vào các giai đoạn tiếp theo.

Đến nay vẫn chưa thể xác định chắc chắn kích thước của Thành Nội (Giai đoạn 1) vì phần phía nam đã bị cư dân hiện đại xây dựng các công trình lên trên. Nhưng cơ bản có thể nhận diện phần mặt thành/lũy rộng trên $3.9 \mathrm{~m}$, mặt thành tập trung nhiều mảnh ngói Cổ Loa, đá, than tro (dài 2.81m) (Hình 18). Ở độ sâu so với mặt Ụ hỏa hồi 
hiện tại 3.50 - 4.04m và có độ cao chênh lệch từ đỉnh thành phía nam về phía bắc chân thành là $76 \mathrm{~cm}$.

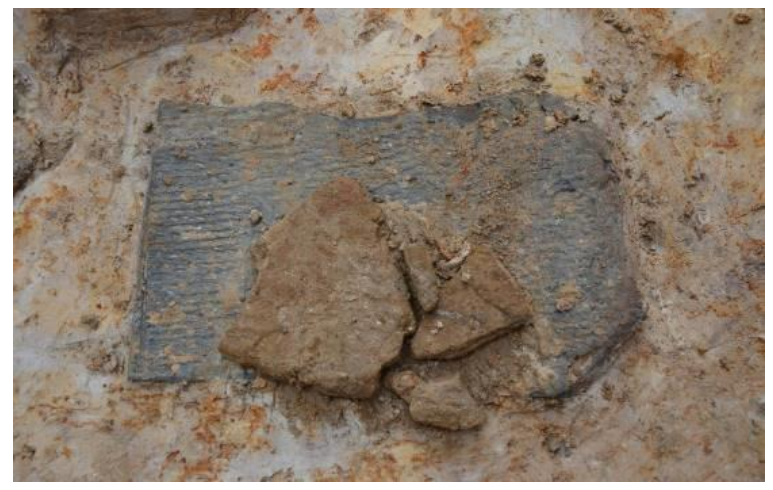

(a)

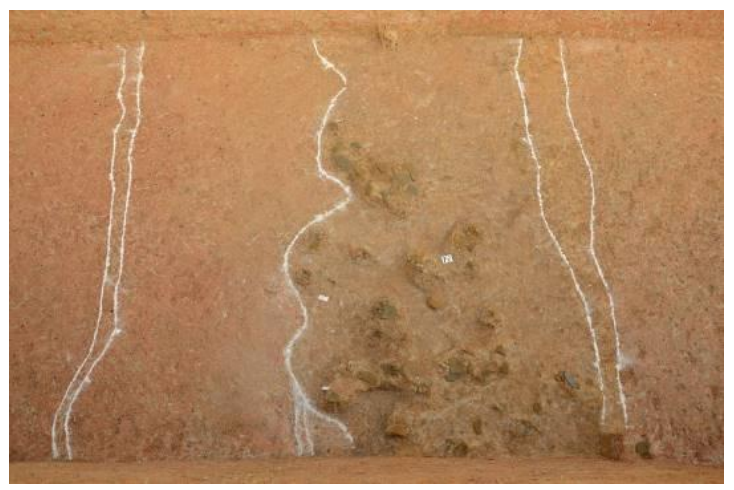

(c)

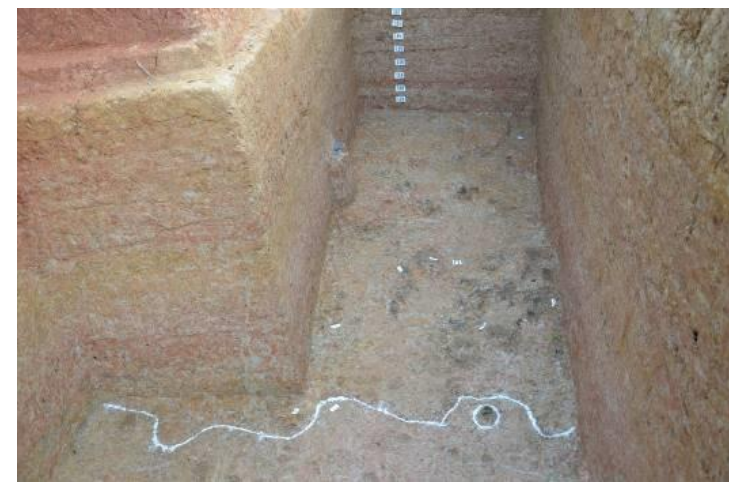

(b)

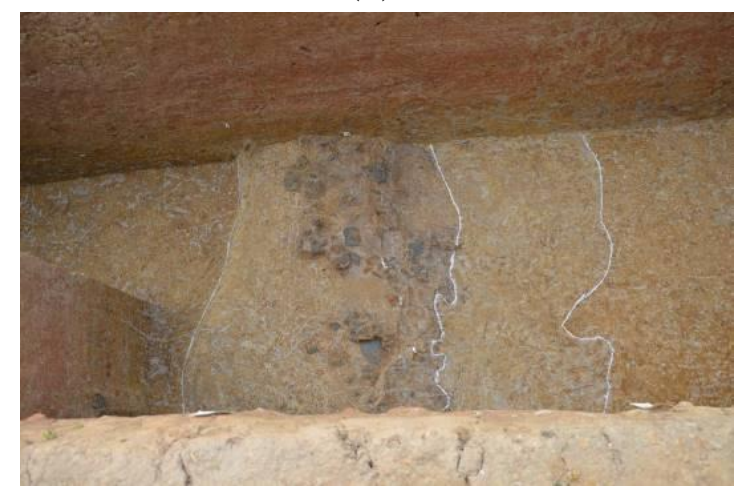

(d)

\section{Hình 18. Ngói Cổ Loa và than tro}

Ghi chú: a) Ngói Cổ Loa trên mặt Thành Nội (Giai đoạn 1); b) Mảnh ngói, than tro - F1 (Giai đoạn 3);

c) Mảnh ngói, than tro - F2 (Giai đoạn 2); và d) Mảnh ngói, đá, than tro - F3 (Giai đoạn 1).

Ụ hỏa hồi (Giai đoạn 1) có chiều dài tính từ phần xuất lộ trong hố H1 - H3 khoảng $23 \mathrm{~m}$, cao trên $1 \mathrm{~m}$, mặt rộng trên $3 \mathrm{~m}$, bề mặt khá bằng phẳng. Theo chúng tôi có thể các giai đoạn đắp thành và Ụ hỏa hồi ở phía đông bắc Thành Nội có năm lần đắp và chia thành bốn giai đoạn: Giai đoạn 1 (lần đắp 1 ); Giai đoạn 2 (lần đắp thêm 2 và 3 ); Giai đoạn 3 (lần đắp thứ 4); Giai đoạn 4 (lần đắp thứ 5 ). Lần đắp $1,2,3$ thuộc giai đoạn Cổ Loa, còn lần đắp thêm thứ 4 , thứ 5 có thể thuộc giai đoạn muộn sau này. Tuy nhiên, để có câu trả lời chính xác về các giai đoạn đắp lũy Thành Nội và Ụ hỏa hồi phía đông bắc, chúng ta phải đợi kết quả phân tích niên đại tuyệt đối trong tương lai.

Di vật bao gồm: i) Ngói Cổ Loa có 832 hiện vật, gồm hai loại ngói cong (815 mảnh âm dương và 17 mảnh ngói bò). Hoa văn trang trí gồm văn thừng trang trí hai mặt ngói, văn thừng trang trí một mặt ngói, trang trí văn thừng trên lưng và ô trám ở mặt bụng viên ngói... Những mảnh ngói Cổ Loa xuất hiện ở lần đắp thêm thứ 3 (Giai đoạn 2) - giai đoạn Cổ Loa; ii) $D i$ vật đá: Có 1 tiêu bản xuất lộ cùng với những mảnh ngói Cổ Loa, nhưng có tọa độ thấp hơn so với lớp gốm. 


\subsubsection{Khai quật địa điểm Thành Nội}

Chúng tôi mở một hố khai quật có diện tích $10 \mathrm{~m}^{2}(5 \times 2 \mathrm{~m})$ tại địa điểm Thành Nội sau khu vực Đền Thượng (gần sân bóng thôn Lan Trì). Hố khai quật có tọa độ 210113'28” vĩ Bắc, $105^{0} 87$ '111” kinh Đông. Vách bắc hố khai quật cách góc Ụ hỏa hồi phía tây bắc $101 \mathrm{~m}$; Vách nam cách góc thành và Ụ hỏa hồi về phía tây nam $25 \mathrm{~m}$.

Thông qua địa tầng chúng tôi bước đầu đưa ra ba giai đoạn đắp lũy Thành Nội tại vị trí khai quật. Tuy nhiên, ở khu vực này đã bị cư dân hiện đại đào/phá nhiều nên có thể những lớp đất đắp thành ở nhiều giai đoạn sau này không còn nữa. Ở khu vực gần Đền Thượng với hiện trạng như hiện nay có thể còn tìm thêm được dấu vết của các lần đắp thành. Tư liệu khai quật Thành Nội xác định, các lớp đất đắp ở Thành Nội có ba giai đoạn với bốn lần đắp như sau (Hình 19):

- Giai đoạn 1 (Lần 1): Dày $75-102 \mathrm{~cm}$, đất laterite màu nâu sẫm, sạn sỏi màu đỏ chiếm tỷ lệ lớn, lẫn đất màu nâu;

- Giai đoạn 2 (Lần 2): Dày 42 - 50cm, đất màu nâu sẫm, màu nâu; Giai đoạn 2 (Lần 3) dày $55-70 \mathrm{~cm}$, đất màu nâu sẫm lẫn sạn sỏi màu đỏ. Nằm dưới bề mặt lần đắp này $20-25 \mathrm{~cm}$ về phía tây có khu vực rộng $47-65 \mathrm{~cm}$, dài $2 \mathrm{~m}$, dày $25-40 \mathrm{~cm}$, tập trung nhiều mảnh ngói Cổ Loa, mảnh đá (dày $30-40 \mathrm{~cm}$ ), lớp than tro (dày $3-5 \mathrm{~cm}$ ). Bề mặt di tích thấp hơn mặt Thành Nội hiện tại về phía tây $73-85 \mathrm{~cm}$ và cách mặt sinh thổ $1.60-1.75 \mathrm{~m}$. Tuy nhiên, di tích này sẽ phát triển về phía bắc và phía nam, rộng về phía tây hố khai quật. Như vậy, bên ngoài Thành Nội cũng có hiện tượng kè mảnh ngói Cổ Loa, mảnh đá như Thành Ngoại, Thành Trung và Thành Nội phía đông bắc;

- Giai đoạn 3 (Lần 4): Dày $50-83 \mathrm{~cm}$, đất laterite màu đỏ hơi vàng, sạn sỏi màu đỏ chiếm tỷ lệ lớn lẫn đất màu nâu sẫm.

Theo chúng tôi có thể các giai đoạn đắp Thành Nội ở vị trí này như sau: Lần đắp 1 (Giai đoạn 1); Lần đắp thêm thứ 2 và thứ 3 (Giai đoạn 2 ) thuộc giai đoạn Cổ Loa. Lần đắp thứ 4 (Giai đoạn 3 ) có thể thuộc giai đoạn muộn sau này. Để có câu trả lời chính xác về các giai đoạn đắp Thành Nội phải đợi kết quả phân tích niên đại tuyệt đối trong tương lai.

Các di vật khảo cổ thu được tập trung trong Giai đoạn 2 (lần đắp 3), bao gồm (Hình 20): i) Ngói Cổ Loa: Có 333 tiêu bản, gồm hai loại ngói cong (311 mảnh ngói âm dương và 22 mảnh ngói bò). Hoa văn trang trí trên ngói gồm các loại: Văn thừng trang trí hai mặt ngói, văn thừng trang trí ở một mặt ngói, trang trí văn thừng trên lưng và ô trám ở mặt bụng viên ngói... Những mảnh ngói Cổ Loa xuất hiện ở lần đắp thêm thứ 3 (Giai đoạn 2) - giai đoạn Cổ Loa; ii) Di vật đá: Có chín tiêu bản, xuất lộ cùng với những mảnh ngói Cổ Loa, nhưng có tọa độ thấp hơn. 


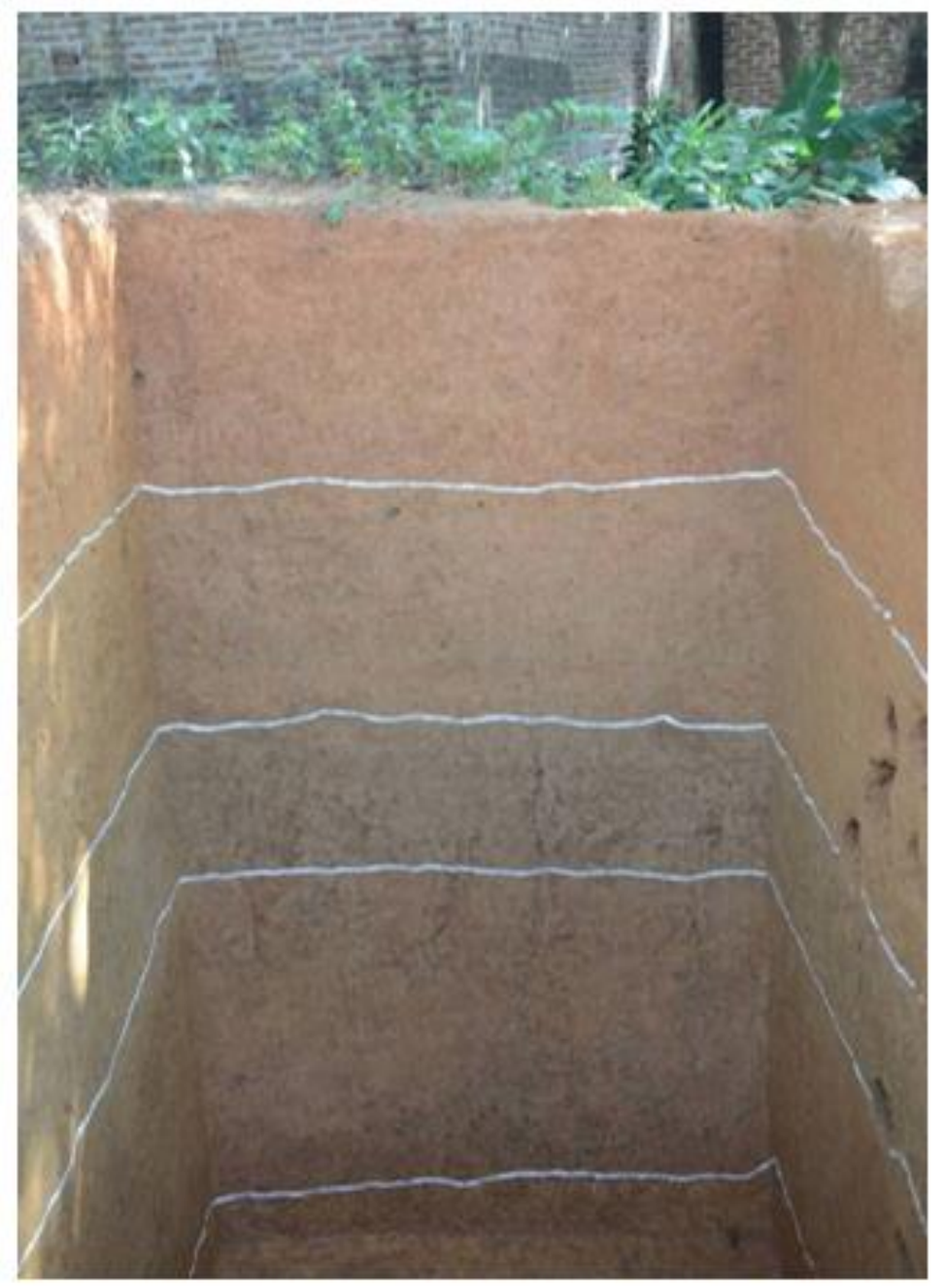

Lần 4 (Giai đoạn 3)

Là̀n 3 (Giai đoạn 2)

Lần 2 (Giai đoạn 2)

Lần 1 (Giai đoạn 1)

\section{Hình 19. Các lớp đất đắp Thành Nội}
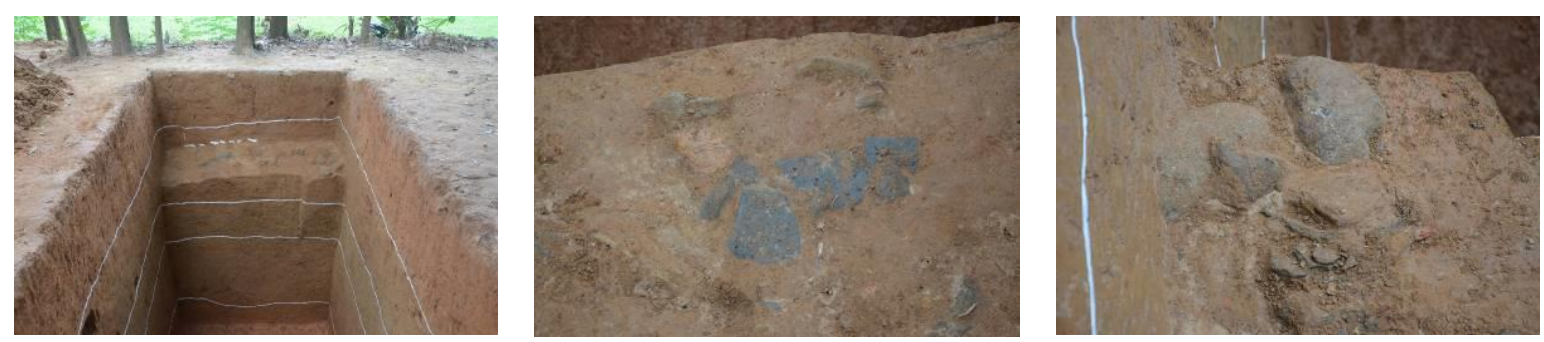

Hình 20. Khu vực tập trung nhiều mảnh ngói, đá và than tro ở lần đắp thứ 3

(Giai đoạn 2) phía tây Thành Nội

\section{NHậN XÉT VÀ KẾT LUẬn}

Kết quả nghiên cứu ba vòng thành từ 2007 - 2014 cùng với kết quả nghiên cứu Thành Ngoại (1970) và Thành Nội (2005) cho thấy kỹ thuật đắp Thành Nội và Ụ hỏa hồi phía đông bắc khác với kỹ thuật đắp đất ở Thành Ngoại, Thành Trung, hay ở vọng 
gác xuất lộ đồ gốm Đông Sơn, đồ sắt và di tích bếp lửa nằm dưới lũy Thành Trung (Hình 23). Sự khác biệt đó là ở chỗ, kỹ thuật đắp Thành Ngoại, Thành Trung hay vọng gác trong giai đoạn Đông Sơn, thành được đắp hình vòng cung; Rồi đến các giai đoạn đắp tiếp theo cách xây dựng cũng có hình dáng như vậy đã làm tăng thêm kích thước của tường thành. Trong khi đó, kỹ thuật đắp Thành Nội, Ụ hỏa hồi phía đông bắc Thành Nội có những lớp đất đắp ở các giai đoạn khác nhau nhưng đều có tính thống nhất và tạo thành mặt phẳng, chứ không đắp đất thành hình vòng cung, không giống kỹ thuật đắp ở Thành Ngoại và Thành Trung.

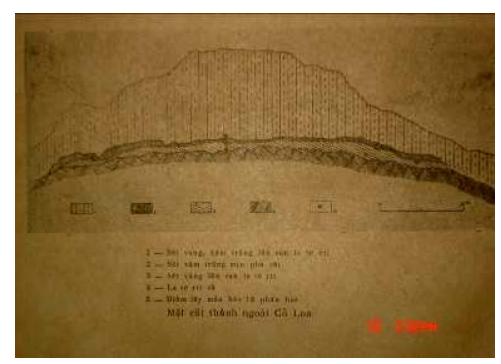

(a)

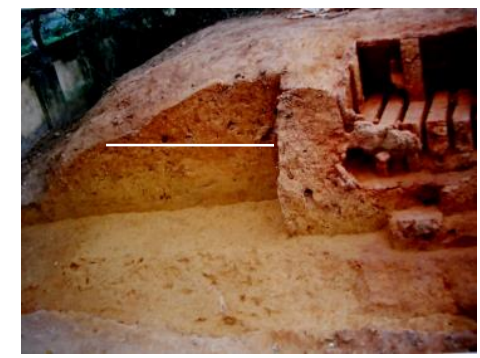

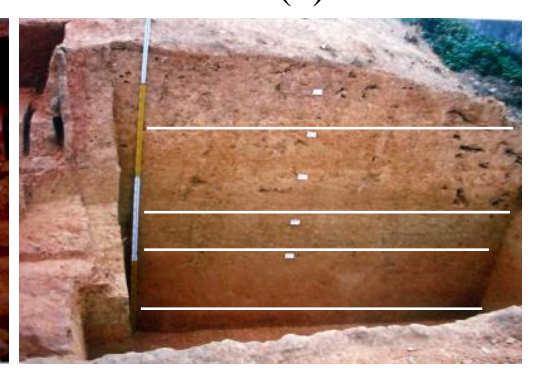

(d)

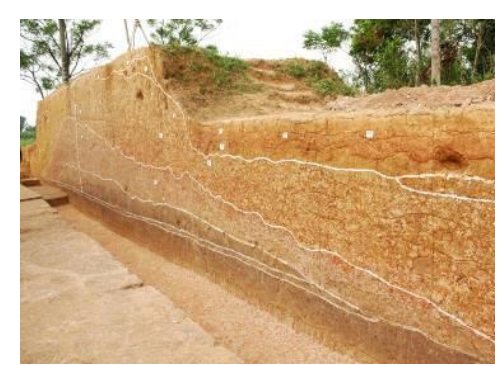

(b)

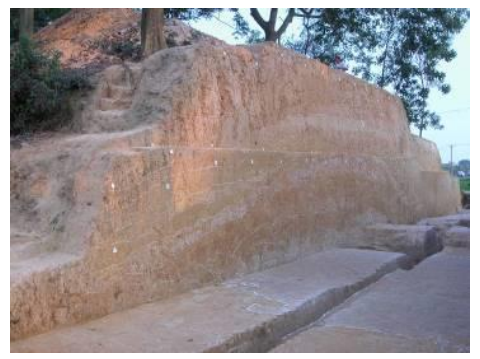

(c)

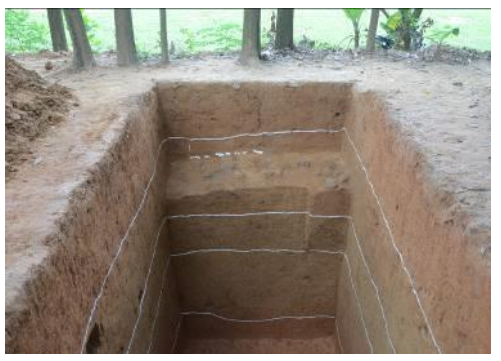

(e)

Hình 21. Mặt cắt các Thành ở các năm nghiên cứu

Ghi chú: a) Mặt cắt Thành Ngoại năm 1970; b)Mặt cắt Thành Ngoại năm 2012;

c) Mặt cắt Thành Trung năm 2007 - 2008; d) Mặt cắt Thành Nội năm 2005; và e) Mặt cắt Thành Nội năm 2014;

Nguồn: Lại (2005); Nguyễn và Vũ (2007).

Kỹ thuật đắp lũy Thành Ngoại khác với kỹ thuật đắp Giai đoạn 2 của Thành Trung (kết quả phân tích AMS năm 2007 - 2008 là 399 - 206BC). Không có kỹ thuật cắt đất như kỹ thuật đắp thành cổ ở Trung Quốc. Phương pháp cắt đất thường được dùng để xây dựng tường thành và nền móng cho các tòa nhà tại văn hoá Long Sơn (khoảng $3,000-1,800 \mathrm{BC}$ ) và các di chỉ thuộc văn hóa Thương (khoảng 1,600 - 1,046BC) (Chang, 1978; 1980). Kỹ thuật cắt đất ở các di chỉ thuộc nhà Hán (Trung Quốc) có xu hướng mỏng và độ dày của các lớp đất là thống nhất, khoảng $12-14 \mathrm{~cm}$, trong khi các lớp đất cắt của Giai đoạn 2 ở Cổ Loa rất dày, thô và thiếu tính đồng nhất (Keeley, 2009). Các tài liệu về các nền văn minh khác nhau cho thấy sử dụng kỹ thuật cắt đất xuất hiện ở các thành phố miền Nam Lưỡng Hà, Inka của Peru và các quốc gia Yoruba ở Châu Phi (Trigger, 2003, tr. 566). 
Căn cứ vào kỹ thuật xây/đắp thành, so sánh với kỹ thuật xây/đắp thành ở các nền văn minh khác, các mẫu phân tích niên đại tuyệt đối ở Thành Trung (Bảng 1 , Bảng 2 , và Bảng 3) thì cả ba vòng thành Cổ Loa đều do An Dương Vương xây dựng nhưng ở các giai đoạn khác nhau. Trong nghiên cứu của Nam, Lại, và Trịnh (2010) về Thành Trung (Cổ Loa) cũng cho rằng không có sự tham gia của người Hán trong xây/đắp Cổ Loa. Nhưng, các tác giả cũng đưa ra giả thuyết không loại trừ khả năng do ảnh hưởng từ người Trung Quốc hoặc dưới sự chỉ đạo của người Trung Quốc trong xây/đắp thành sau giai đoạn An Dương Vương. Như vậy, vấn đề có hay không sự tham gia của nhà Hán vào xây dựng thành Cổ Loa Giai đoạn 2 cần tiếp tục nghiên cứu.

Vấn đề đặt ra là các lần đắp ở Thành Nội và Ụ hỏa hồi cách nhau như thế nào hay đều được đắp cùng thời gian với giai đoạn Cổ Loa cũng cần nghiên cứu và thảo luận tiếp. Hiện tại chúng tôi chưa có kết quả phân tích niên đại tuyệt đối bằng phương pháp Carbon phóng xạ (C14) về các giai đoạn đắp Thành Ngoại (2012), Thành Nội và Ụ hỏa hồi (năm 2014). Nhưng dựa trên kết quả phân tích niên đại tuyệt đối và tư liệu khảo cổ học được phát hiện ở Thành Trung năm 2007 - 2008 để đưa ra các giai đoạn đắp thành như trong các Bảng 1 , Bảng 2, và Bảng 3 (Hình 22).

Có thể nói, với sự hiện diện của các mảnh ngói và đá là một phần của văn hóa vật chất ở Cổ Loa. Khả năng thứ nhất có thể xảy ra, đó là vật liệu xây dựng của một cấu trúc dạng có mái được dựng lên dọc theo bề mặt gốc của tường thành trong giai đoạn giữa có tính chất để bảo vệ chống lại mưa hay bị đối phương tấn công. Khả năng thứ hai là đá và ngói tập trung ở những vị trí đó là cố ý để bảo vệ tường thành chống lại sự xói mòn do mưa. Những mảnh vỡ của đá và ngói mảnh dường như tồn tại dọc theo cùng một lớp địa tầng ở cả Thành Trung, Thành Ngoại, Thành Nội, và Ụ hỏa hồi. Nhìn chung, đất để đắp thành lũy được cư dân Cổ Loa khai thác từ hào nằm bên ngoài thành. Địa tầng của thành là một cột đảo ngược so với hào; Rất có thể, phần lớn tường thành được xây dựng liên tục và trong thời gian tương đối ngắn.

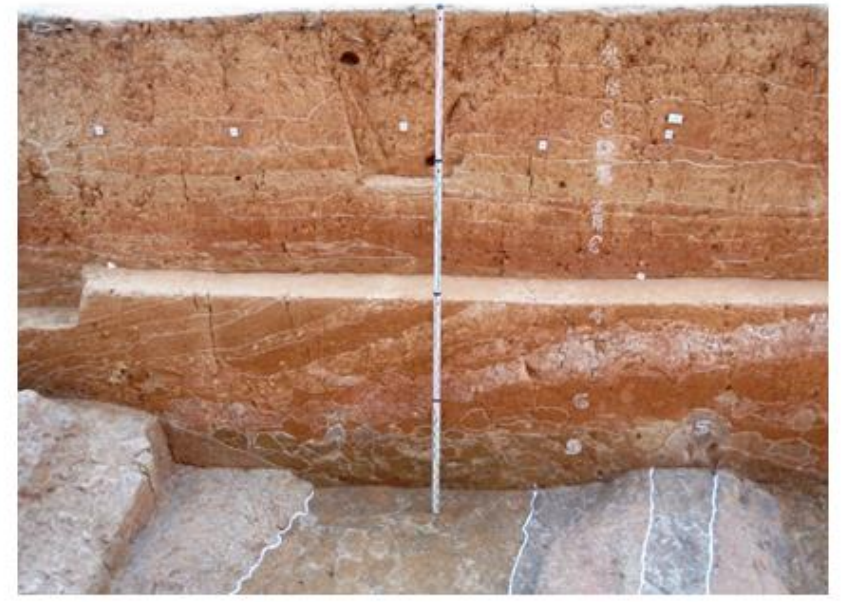

Góc của ụ phòng vệ

Cấu trúc có tính phòng thủ
Lần 5 (Giai đoạn 3)

Lần 4 (Giai đoạn 2)

Lần 3 (Giai đoạn 2)

Lần 2 (Giai đoạn 2)

Lần 1 (Giai đoạn 1)

Hình 22. Thành lũy giai đoạn Đông Sơn (muộn) nằm dưới Thành Trung hiện nay và các lớp đắp Thành Trung khai quật năm 2007 - 2008 
Bảng 1. Niên đại AMS mẫu than khu vực lẫn gốm Đông Sơn trong ụ phòng vệ và hào lần đắp thứ nhất (Giai đoạn 1) ở Thành Trung năm 2007 - 2008

\begin{tabular}{llll}
\hline Mẫu & Tuổi Carbon & $\begin{array}{l}\text { Niên đại đã } \\
\text { hiệu chînh (1-Sigma) }\end{array}$ & $\begin{array}{l}\text { Niên đại đã } \\
\text { hiệu chỉnh (2-Sigma) }\end{array}$ \\
\hline \multicolumn{2}{l}{ Mẫu từ nền ụ phòng vệ } & & \\
07TTH1CS138 & $2150 \pm 43 \mathrm{BP}$ & $351-111 \mathrm{BC}$ & $359-54 \mathrm{BC}$ \\
07TTH1CS139 & $2186 \pm 44 \mathrm{BP}$ & $358-191 \mathrm{BC}$ & $384-114 \mathrm{BC}$ \\
Mẫu từ hào & & & \\
07TTH1CS116 & $2365 \pm 52 \mathrm{BP}$ & $520-387 \mathrm{BC}$ & $751-260 \mathrm{BC}$ \\
07TTH1CS117 & $2446 \pm 83 \mathrm{BP}$ & $749-410 \mathrm{BC}$ & $779-398 \mathrm{BC}$ \\
07TTH1CS118 & $2392 \pm 51 \mathrm{BP}$ & $704-397 \mathrm{BC}$ & $752-387 \mathrm{BC}$ \\
07TTH1CS120 & $2327 \pm 52 \mathrm{BP}$ & $506-236 \mathrm{BC}$ & $727-207 \mathrm{BC}$ \\
07TTH1CS122 & $2205 \pm 31 \mathrm{BP}$ & $338-204 \mathrm{BC}$ & $377-197 \mathrm{BC}$ \\
07TTH1CS135 & $2154 \pm 43 \mathrm{BP}$ & $353-113 \mathrm{BC}$ & $360-56 \mathrm{BC}$ \\
07TTH1CS136 & $2251 \pm 22 \mathrm{BP}$ & $385-234 \mathrm{BC}$ & $391-209 \mathrm{BC}$ \\
07TTH1CS137 & $2192 \pm 33 \mathrm{BP}$ & $356-199 \mathrm{BC}$ & $370-174 \mathrm{BC}$ \\
07TTH1CS140 & $2282 \pm 30 \mathrm{BP}$ & $397-259 \mathrm{BC}$ & $402-221 \mathrm{BC}$ \\
\hline
\end{tabular}

Bảng 2. Niên đại AMS mẫu than lẫn ngói Cổ Loa từ lần đắp thành thứ 2 - thứ 4 (Giai đoạn 2) ở Thành Trung năm 2007 - 2008

\begin{tabular}{lllll}
\hline Mẫu & Lần đắp & Niên đại C14 & $\begin{array}{l}\text { Niên đại đã } \\
\text { hiệu chỉnh (1-Sigma) }\end{array}$ & $\begin{array}{l}\text { Niên đại đã } \\
\text { hiệu chỉnh (2-Sigma) }\end{array}$ \\
\hline 07TTH1CS110 & 2 & $2264 \pm 39 \mathrm{BP}$ & $392-233 \mathrm{BC}$ & $399-206 \mathrm{BC}$ \\
07TTH1CS88 & 3 & $2253 \pm 39 \mathrm{BP}$ & $389-215 \mathrm{BC}$ & $396-204 \mathrm{BC}$ \\
07TTH1CS111 & 3 & $2234 \pm 41 \mathrm{BP}$ & $380-210 \mathrm{BC}$ & $389-203 \mathrm{BC}$ \\
07TTH1CS88 & 3 & $2184 \pm 34 \mathrm{BP}$ & $356-192 \mathrm{BC}$ & $375-165 \mathrm{BC}$ \\
07TTH1CS76 & 3 & $2187 \pm 33 \mathrm{BP}$ & $356-196 \mathrm{BC}$ & $370-170 \mathrm{BC}$ \\
07TTH1CS41 & 4 & $2184 \pm 43 \mathrm{BP}$ & $357-184 \mathrm{BC}$ & $382-154 \mathrm{BC}$ \\
07TTH1CS69 & 4 & $2170 \pm 33 \mathrm{BP}$ & $353-173 \mathrm{BC}$ & $363-113 \mathrm{BC}$ \\
07TTH1CS70 & 4 & $2139 \pm 33 \mathrm{BP}$ & $344-111 \mathrm{BC}$ & $353-54 \mathrm{BC}$ \\
07TTH1CS9 & 4 & $2136 \pm 44 \mathrm{BP}$ & $347-93 \mathrm{BC}$ & $357-46 \mathrm{BC}$ \\
07TTH1CS63 & 4 & $2116 \pm 43 \mathrm{BP}$ & $198-59 \mathrm{BC}$ & $353-4 \mathrm{BC}$ \\
07TTH1CS50 & 4 & $2093 \pm 43 \mathrm{BP}$ & $168-54 \mathrm{BC}$ & $345 \mathrm{BC}-2 \mathrm{AD}$ \\
\hline
\end{tabular}




\section{Bảng 3. Các giai đoạn đắp thành và kích thước ở địa điểm Thành Trung khai quật $2007-2008$}

\begin{tabular}{lllll}
\hline $\begin{array}{l}\text { Lần đắp } \\
\text { (sớm đến muộn) }\end{array}$ & Xây dựng & Chiều cao & Chiều rộng & Niên đại \\
\hline 1 & $\begin{array}{l}\text { Thành đất sét và được tạo } \\
\text { thành ụ đất }\end{array}$ & $1.0 \mathrm{~m}$ & $1.8 \mathrm{~m}$ & $4 \mathrm{BC}$ \\
2 & Đống đất & $2.0 \mathrm{~m}$ & $17.0 \mathrm{~m}$ & $3 \mathrm{BC}$ \\
3 & Lớp đất dày được đầm nện & $2.5 \mathrm{~m}$ & $24.0 \mathrm{~m}$ & \\
4 & Đống đất & $3.0 \mathrm{~m}$ & $24.0-25.0 \mathrm{~m}$ & $1 \mathrm{AD}$ \\
5 & Lớp đất mỏng được đầm nện & $4.0 \mathrm{~m}$ & $26.0 \mathrm{~m}$ & $15-16 \mathrm{AD}$ \\
\hline
\end{tabular}

Thành Cổ Loa do vua An Dương Vương xây dựng là sự kế thừa tòa thành có trước; đây là tòa thành của làng phòng thủ tương ứng với chế độ xã hội dạng Chiefdom ${ }^{1}$. Thành Cổ Loa thời An Dương Vương được xây đắp có quy mô to lớn gấp nhiều lần so với cấu trúc thành trước đó; Khối lượng công việc xây đắp thành chắc chắn tương ứng với một chế độ xã hội cao cấp dạng nhà nước sơ khai. Việc huy động nhân công xây đắp thành phải có người đứng đầu quản lý các hoạt động chung như nhà nước Âu Lạc. Kết quả khai quật cho thấy kỹ thuật đắp, quy mô và hình dáng của thành Cổ Loa là truyền thống của người Việt, rất khác với những quy định cụ thể hay kỹ thuật trong cách xây dựng thành của nhà Hán.

Thành Cổ Loa được xây dựng từ giai đoạn An Dương Vương và tiếp tục được các giai đoạn sau này tu bổ và sử dụng. Từ nguồn sử liệu thành văn kết hợp với tư liệu khai quật khảo cổ học ở Thành Ngoại (1970), Thành Nội (2005), lũy hào Thành Trung (2007 - 2008), Thành Ngoại (2012), và Thành Nội, Ụ hỏa hồi (2014) bước đầu góp thêm tư liệu để làm sáng tỏ về lũy, hào của cư dân giai đoạn Đông Sơn (muộn) ở Cổ Loa, rồi đến giai đoạn đắp thành thời vua An Dương Vương. Ngoài ra, khai quật ở Thành Trung và Thành Ngoại còn ghi nhận thêm các lần đắp thành vào một số giai đoạn lịch sử nào đó có lần thuộc thời hậu Lê.

Nguồn tư liệu hiện biết cho thấy, di tích và lịch sử thành Cổ Loa là một chính thể kiểu nhà nước bản địa xuất hiện trong giai đoạn văn hóa Đông Sơn trước khi bị nhà Hán đô hộ. Kết quả khai quật các di tích ở đây trong hai thập kỷ qua xác định quy mô và kích thước lớn của thành Cổ Loa và những công trình phòng thủ rất hoành tráng. Tư liệu trên cũng gợi ý về một cấp độ cao của sự tập trung chính trị, là sự cần thiết để quy hoạch xây dựng và huy động nguồn lực cần thiết. Rất có thể, các cộng đồng cư dân Việt cổ đã quen với các công trình công cộng được xây dựng trước khi xây dựng thành Cổ Loa, những công trình như thế có quy mô nhỏ (như mương, đê điều, đường đi...) và diễn

'Một thủ lĩnh là một hình thức tổ chức chính trị phân cấp trong các xã hội phi công nghiệp thường dựa trên mối quan hệ họ hàng và trong đó sự lãnh đạo chính thức được độc quyền bởi các thành viên cao cấp hợp pháp của các gia đình hoặc 'nhà' được chọn. 
ra trong thời gian nông nhàn (Larew, 2003, tr. 40-41). Khi nghiên cứu về các di tích ở đây, Larew (2003, tr. 41) đã nhận định, trước khi thành Cổ Loa được xây dựng, khu vực châu thổ Sông Hồng chưa có một di tích nào có kích thước lớn như Cô Loa; Và để xây dựng được thành lớn như Cổ Loa chắc hẵn cần phải có một lực lượng quân sự hùng mạnh, với sự quản lý kiểu nhà nước và tập trung hóa mới thực hiện được. Hơn nữa, những yêu cầu cao về lao động cũng hàm ý là mật độ dân số cao; Dân số đông không chỉ phục vụ cho xây dựng mà còn đáp ứng cho hoạt động nông nghiệp trồng lúa nước ở khu vực đồng bằng châu thổ sông Hồng.

Với nguồn tư liệu khảo cổ học và thư tịch cổ có thể khẳng định, thành Cổ Loa là tòa thành được đắp bằng đất cùng các cấu kiện ngói và đá sớm nhất, quy mô to lớn nhất ở Việt Nam và Đông Nam Á. Thành cổ này do An Dương Vương đắp vào thế kỷ III IIBC. Đây là tòa thành vừa có chức năng bảo vệ kinh đô, bảo vệ nhà vua và hoàng gia và vừa là căn cứ quân sự có tính phòng thủ vững chắn.
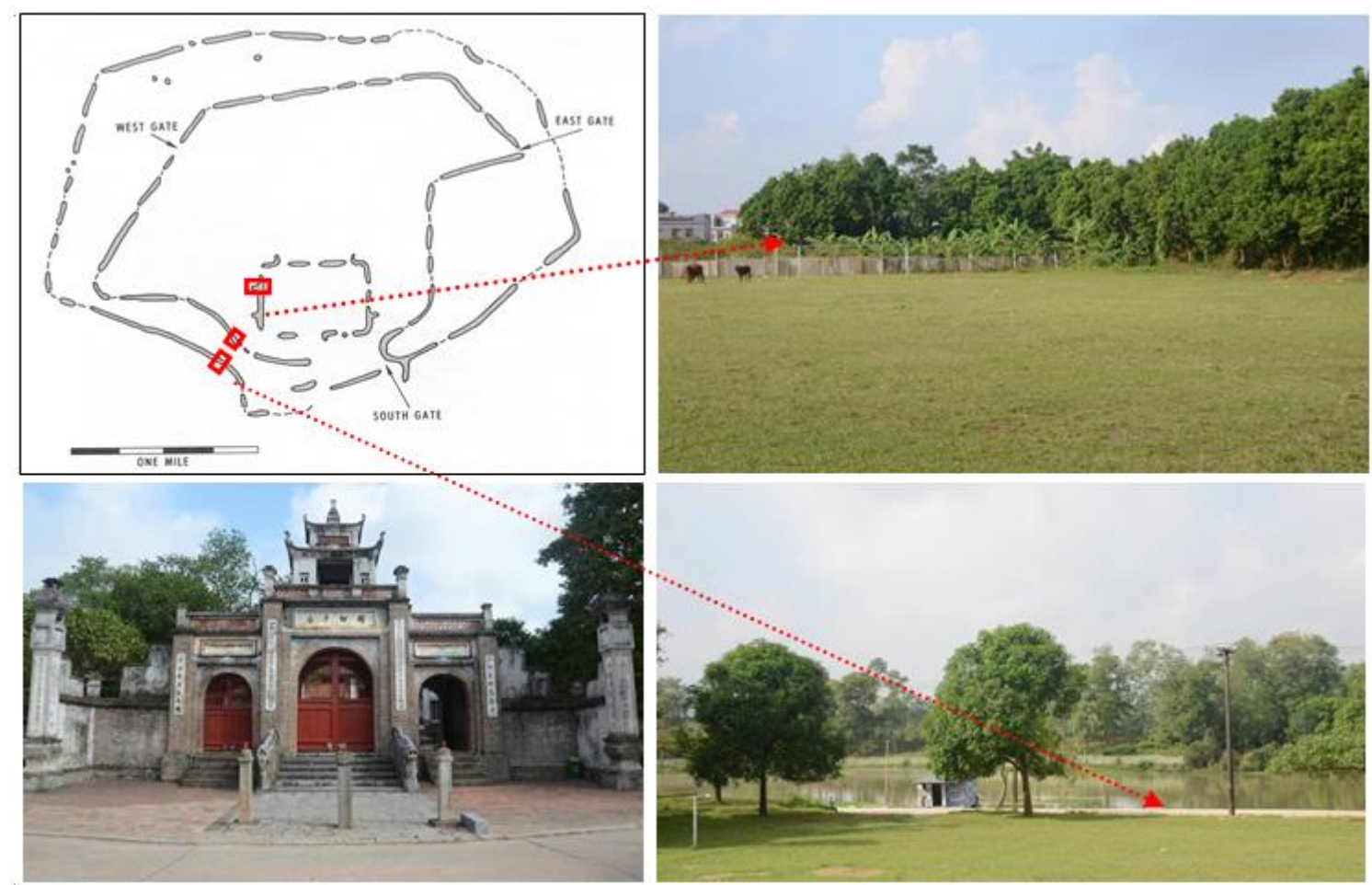

Hình 23. Vị trí đề xuất khai quật lũy phía tây nam Thành Ngoại, Thành Trung, lũy - Ụ hỏa hồi Thành Nội, hào Thành Ngoại và xây dụng bảo tàng ngoài trò̀i

\author{
Nguồn: Bezacier (1972) và Trịnh (2014).
}

Giá trị nhất của khu di tích Cổ Loa là di tồn văn hoá của một kinh đô cổ nhất khu vực Đông Nam Á. Cách xây/đắp thành lợi dụng triệt để điều kiện tự nhiên có sẵn trong khu vực để đào đất đắp thành và đào hào. Hệ thống sông được dùng làm hào tự nhiên cho Thành Ngoại, và sông còn cung cấp nước cho cả hệ thống hào của tòa thành. Ngoài ra, nhiều gò/đống hay doi đất cao cũng được đắp nối lại và cao thêm thành một bộ phận hữu cơ của tòa thành. Có thể nói, thành Cổ Loa là sự sáng tạo độc đáo trong 
cách xây dựng của người Việt cổ trong công cuộc giữ nước và chống giặc ngoại xâm. Dưới góc độ văn hóa, thành Cổ Loa là di sản văn hóa độc đáo; Là bằng chứng về sự sáng tạo, về trình độ kỹ thuật xây dựng, cũng như tinh hoa văn hóa của người Việt cổ. Việc tiếp tục khai quật mới, bảo tồn (Hình 23) và phát huy di sản khảo cổ là việc làm cần thiết của thế hệ hôm nay và mai sau.

Từ Kinh đô Văn Lang thời các vua Hùng ở Bạch Hạc (Việt Trì, Phú Thọ), đến Kinh đô Cổ Loa thời An Dương Vương (Đông Anh, Hà Nội), Kinh đô Hoa Lư thời Đinh - Tiền Lê (Hoa Lư, Ninh Bình), rồi đến kinh đô Thăng Long các thời Lý - Trần Lê,... mỗi lần dịch chuyển kinh đô là một bước tiến dài của lịch sử, phù hợp với xu thế phát triển của lịch sử và do nhu cầu mở mang và phát triển đất nước của các triều đại. Mỗi cố đô đều có một hệ giá trị riêng mà chỉ mình nó có. Vấn đề tìm hiểu về mối quan hệ giữa kinh đô Cổ Loa với các kinh đô, như: Văn Lang, Hoa Lư, Thăng Long là nhằm khẳng định giá trị truyền thống, những nét văn hóa đặc sắc có giá trị ở mỗi giai đoạn lịch sử.

Vấn đề bảo tồn và phát huy giá trị di sản văn hóa liên quan đến khu di tích Cổ Loa là vấn đề cần thiết trong giáo dục cho thế hệ trẻ hôm nay và mai sau về tinh thần độc lập dân tộc, truyền thống chống xâm lăng, và phát huy truyền thống lịch sử - văn hóa của cha ông. Khai thác tốt vấn đề lịch sử - văn hóa ở khu di tích Cổ Loa; có kế hoạch xây dựng một không gian văn hóa lịch sử, hay không gian văn hóa tâm linh phù hợp với truyền thống và đương đại sẽ góp phần tích cực vào công tác giáo dục. Việc làm trên cũng đồng nghĩa là đáp ứng được nhu cầu hưởng thụ văn hóa của các tầng lớp nhân dân hôm nay và tương lai.

Để bảo tồn và phát huy những di sản thành Cổ Loa thì phải nghiên cứu để lựa chọn một khu tiêu biểu, hay các di tích tiêu biểu nhất của khu di tích Cổ Loa để quy hoạch, bảo tồn, trung tu, nghiên cứu, nhằm giúp du khách trong và ngoài nước nhận diện toàn bộ khu di tích. Và, công tác nghiên cứu lâu dài các di tích ở Cổ Loa cũng là việc làm cấp thiết hiện nay.

\section{LÒ̀I CẢM ONN}

Để có kết quả nghiên cứu này, chúng tôi tỏ lòng biết ơn sâu sắc tới sự quan tâm và chỉ đạo của Viện Hàn lâm Khoa học Xã hội Việt Nam; Bộ Văn hóa, Thể thao, và Du lịch; Cục Di sản Văn hóa; Sở Văn hóa, Thể thao và Du lịch Hà Nội; Ban Quản lý Di tích và Danh thắng Hà Nội; Trung tâm Bảo tồn Di sản Thăng Long - Hà Nội; Ban Quản lý Di tích Cổ Loa; Ban Hợp tác quốc tế; Viện Hàn lâm Khoa học Xã hội Việt Nam; Viện Khảo cổ học; UBND huyện Đông Anh; Phòng Văn hóa - Thông tin huyện Đông Anh; UBND xã Cổ Loa; và bà con nhân dân xã Cổ Loa.

Xin trân trọng cảm ơn PGS.TS. Tống Trung Tín, PGS.TS. Nguyễn Giang Hải, PGS.TS. Bùi Văn Liêm, TS. Nguyễn Văn Sơn, PGS.TS. Lại Văn Tới, TS. Nguyễn Huy Hạnh, CN. Nguyễn Đăng Cường, ThS. Phạm Thanh Sơn, ThS. Nguyễn Thị Hảo, CN. Nguyễn Thị Thủy, CN. Đỗ Đức Tuệ, CN. Bùi Văn Hùng, CN. Bùi Xuân Tuân; Khoa Nhân học và Khảo cổ học Đại học Illinois, Chicago; Khoa Nhân học Đại học Wisconsin 
- Madison, Hoa Kỳ; GS.TS. Lawrence Keeley, GS.TS. Laura Junker, PGS.TS. Debra Greene, TS. Mcgillivray Tegan Skye đã hợp tác nghiên cứu.

\section{TÀI LIỆU THAM KHẢO}

Bezacier, C. (1972). Le Viêt-nam. Paris, France: Éditions A. et J. Picard.

Chang, K. C. (1978). The archaeology of China. New Haven, USA: Yale University Press.

Chang, K. C. (1980). Shang civilization. New Haven, USA: Yale University Press.

Keeley, L. (2009). Personal communication.

Lại, V. T. (2005). Một số hình ảnh khai quật Thành Nội năm 2005. Hà Nội, Việt Nam: Viện Khảo cổ học.

Larew, M. (2003). Thuc Phan, Cao Tong, and the transfer of military technology in third century BC Vietnam. East Asian Science, Technology, and Medicine, 21, 12-47.

Nam, C. K., Lại, V. T., \& Trịnh, H. H. (2010). Thành lũy, chiến tranh và chính trị tập trung: Qua kết quả khai quật lũy - hào Thành Trung (Cổ Loa, Đông Anh, Hà Nội). Tạp chí Khảo cổ hoc, (3), 46-62.

Nguyễn, Q. N., \& Vũ, V. Q. (2007). Địa chí Cổ Loa. Hà Nội, Việt Nam: NXB. Hà Nội.

Trigger, B. (2003). Understanding early civilizations. Cambridge, UK: Cambridge University Press.

Trịnh , H. H. (2014). Phụ lục minh họa khai quật khu di tích Cổ Loa năm 2014. Hà Nội, Việt Nam: Viện Khảo cổ học. 